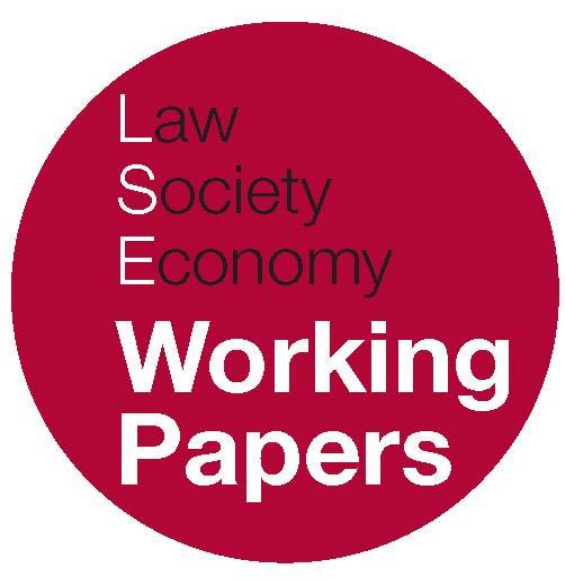

\title{
Corporate Law and Self-Regulation
}

\section{David Kershaw}

LSE Law, Society and Economy Working Papers 5/2015

London School of Economics and Political Science

Law Department

This paper can be downloaded without charge from LSE Law, Society and Economy Working Papers at: www.lse.ac.uk/collections/law/wps/wps.htm and the Social Sciences Research Network electronic library at: http://ssrn.com/abstract $=3574201$.

(C) David Kershaw. Users may download and/or print one copy to facilitate their private study or for non-commercial research. Users may not engage in further distribution of this material or use it for any profit-making activities or any other form of commercial gain. 


\title{
Corporate Law and Self-Regulation
}

\author{
David Kershaw*
}

\begin{abstract}
This paper explores the different ways in which market actors are "co-opted" as corporate law regulators. It considers the the preconditions for generating "endogenous selfregulation" through the lens of the formation and operation of the UK Takeover Code and Panel. The paper argues that its incontrovertible success as a command, control and surveillance regulator is in large part attributable to merchant (investment) banking control over the production of the original Code and the ways in which the Code generates direct and indirect income opportunities for investment bankers in takeover activity, referred to in the paper as "bribing the quarterback". The paper also uses the Takeover Panel example to explore the unexpected regulatory biases that are generated by the survival and legitimacy concerns of the self-regulator itself. From endogenous self-regulation, the paper moves onto consider "market-controlled" regulation where the state directly co-opts market actors as regualators. Using the example of "comply or explain" corporate governance codes the paper explores the powerful market-based enforcement drivers and argues that these drivers interact with a "comply or explain" regulatory outlook that is likely to, and does, lead to sub-optimal regulation that overweights accountability concerns. Setting these regulatory effects alongside the regulatory biases identified in the analysis of the Takeover Code, the paper shows that the regulatory biases generated by self-regulation are more muli-faceted than, and often inconsistent with, the standard account that self-regulation is likely to generate rules that favour the regulated.
\end{abstract}

\footnotetext{
${ }^{*}$ Professor of Law, London School of Economics and Political Science. This paper is a version of the a Chapter on Corporate Law and Self-Regulation forthcoming in the Oxford Handbook on Corporate Law and Governance. My thanks to the participants at the Columbia Law School conference on the OXFORD HANDBOOK OF CORPORATE LAW AND GOVERNANCE, with particular thanks to John Armour, Paul Davies, Michael Klausner, Georg Ringe and Edmund Schuster.
} 


\section{INTRODUCTION}

Typically when we think about the regulation of corporate and business life we ask two questions: why should we regulate; and how should we regulate? The first question invokes justifications for interfering with the free contracting process amongst corporate actors, both within and outside of the corporation. The second question explores whether we should insist on corporations following a particular form of behaviour through mandatory rules, or merely provide weighted guidance on rule choice through default rules that can be opted-out of. A third question relating to corporate regulation is less prominent and is the subject of this chapter: who should do the regulating? Traditionally we have thought about this question through the dichotomy of state versus market. Not 'the market' as a mechanism which generates regulatory benefits, but the market as a collection of actors capable of coordinating to produce and enforce rules regulating their activities. Through this lens we ask: in what, if any, circumstances should market actors regulate corporate activity themselves by endogenously generating and enforcing regulation without overt state involvement; and in what, if any, circumstances is such endogenous self-regulation likely to occur in practice?

Of course the rigid dichotomy of the state as regulator versus the market as self-regulator does not do justice to the different ways in which the state and the market interact to produce corporate law and regulation. In some sense both the state and the market are always involved in the production of regulation: the state's deference to self-regulation is inimical to its formation; the market forms state regulation through consultation, repeat player activity and lobbying. However, in this chapter we are interested not in the ways in which the market moulds and influences regulation but in the circumstances in which it actually controls the production and enforcement of that regulation. Endogenous selfregulation is the ideal type of such regulation, but it is not the only one. Where 
there are regulatory benefits for the state to defer to the market to generate and enforce rules, the state, cognisant of these benefits, may command the market, collectively or individually, to generate regulation or to engage in practices that lead to targeted norm formation. We might view this type of regulation as forced self-regulation. We refer to this form of regulation in the chapter as market-controlled regulation and distinguish it from self-regulation which the chapter will view as the (quasi-) endogenous production of regulation in the absence of legal instruction.

The purpose of this Chapter is to explore (i) the conditions in which self- and market controlled regulation arise in the field of corporate law, and (ii) the practical and substantive effects of relying on these modes of regulation. We explore these issues primarily through the lens of the dominant real-world examples of self- and market-controlled regulation in the field of corporate law; examples which are often lauded by regulators and commentators alike as model examples of these forms of regulation. They are: the UK Takeover Code and the Takeover Panel created in 1968; and the 'comply or explain' approach to the regulation of board structure and composition, pioneered in the UK in the early 1990s. The chapter is concerned both with exploring the conditions of their creation and success but also, in these conditions, exploring the scope for their replication in other jurisdictions.

\section{FORMS AND PRE-CONDITIONS}

\section{ENDOGENOUS SELF-REgULATION OF CORPORATE ACTIVITY}

Self-regulation as an ideal theoretical type is said to generate several benefits. Selfregulation is cheap and imposes no direct cost on the state treasury: the marketplace pays for its own regulation. ${ }^{1}$ In addition to such direct cost benefits, self-regulation has clear potential regulatory benefits. First and foremost, it is a means of addressing often acute knowledge and information asymmetries afflicting the relationship between the regulator and the regulated constituency. Market actors live the regulated activity and, accordingly, both understand the problems and issues that are generated by such activity and understand the means for most efficiently counteracting such problems through regulation. In contrast, state regulators, even ones with revolving doors from and back into practice, have partial vision and understanding of such activity and are more likely therefore to craft sub-optimal regulation that neither deals with the actual problems and, worse, imposes unnecessary costs on such activity. This is compounded by the them against us lens generated by state regulation which disincentives information

\footnotetext{
${ }^{1}$ Of course this may be viewed simply as a form of indirect taxation as the costs of the regulation will be passed through to the consumers in the market place. Furthermore, there is no reason why state regulation cannot impose the costs directly on market players through a regulatory levy - which again is likely to be be passed through to end users.
} 
sharing as a result, inter alia, of the unpredictability of how a state regulator might respond to shared information about market practices. In contrast, the market's 'ownership' of the regulatory space both promotes information sharing with the self-regulator and, in theory, promotes behavioural norms which foster compliance. The second, well traversed, ${ }^{2}$ benefit of self-regulation is that it is able to respond more quickly to new forms of activity that require regulation. Not only, for the reasons set forth above, is the self-regulator likely to be aware of the problem earlier, it is also not constrained by the procedures, checks and balances associated with state action through primary or secondary legislation or through an authorised regulator.

Clearly, however, one needs to be wary of such broad brush claims about the benefits of self-regulation. State regulatory forms, particularly regulatory bodies with rule-making authority, have the capacity to move relatively quickly. And selfregulatory bodies also typically provide for time-consuming procedures to effect rule changes. This is because public expectations of due process and consultation typically inform non-state as well as state bodies. And not all forms of corporate activity generate acute information asymmetries between the regulator and the regulated. Corporate and audit scandals in the last two decades, as well as the Global Financial Crisis, have illuminated areas of corporate activity where such asymmetries clearly exist such as the accounting for off-balance sheet transactions or complex derivative instruments such as collateralised debt obligations. However, in many areas of corporate life, although we find market innovation and smart structuring, the conflict surrounding such activity typically renders it visible and comprehensible. For example, innovative activity in the market for corporate control has typically been transparent because of the conflict it has generated. Consider, for example, takeover defences in the 1960s, 70s and 80s or the conflicts over the use of equity swaps in the 2000s. In these areas, claims that selfregulation addresses asymmetries of knowledge and information are overstated because the asymmetries are insignificant.

As with the benefits of self-regulation, its potential costs have been thoroughly explored. Most importantly in this regard is the concern that the selfregulator will abuse its position and its knowledge and information advantage to craft rules that enhance its welfare position at the expense of other affected parties that have no control or influence over the rule making and enforcement process. State regulators are, of course, not immune from rent seeking but are thought certainly in the eyes of the state regulators themselves! - more able to resist pressures from market constituents and more likely to be able to craft rules that are not biased in favour of any particular constituency. The extent to which a selfregulator is able to bias the rules in favour of market actors is a function of several factors. First, whether or not other non-participating parties are thought to be

2 See for example, Robert Baldwin, Martin Cave and Martin Lodge, Understanding Regulation: Theory, Strategy and Practice (2011). 
affected by the activity in question. Where the activity is thought only to affect the direct parties involved (or where such third-party effects although real are very opaque), then the independence concern will be (or will be seen to be) less pressing so long as all affected market participants have a voice in such selfregulation. It is in such areas in particular where the welfare case for self-regulation is a strong one. Secondly, the extent to which bias is a concern is dependent on the alignment, or lack thereof, of the interests of the self-regulatory rule-maker and the perceived interests of society. If, for example, institutional shareholder groups exercise self-regulatory authority and the prevailing political and social norms view the advancement of shareholder interests as congruent with social welfare, then any such rule-bias is unproblematic. Thirdly, the extent of this bias problem is, paradoxically, connected to one of the purported key benefits of selfregulation: the knowledge and information asymmetries of market actors. Where such asymmetries are significant, self-regulatory actors have more room to deploy self-interest as the ability of the state and other non-state actors, such as the financial press, to assess and monitor whether the rules are biased is much diminished. This means that when we think about the welfare implications of selfversus state- regulation we find that both the benefits and the costs are higher where knowledge and information asymmetries are significant.

The second consensus drawback with self-regulation is the concern that the self-regulator is unlikely to enforce the rules against its own. There are two reasons given for this: the absence of the enforcement apparatus of the state and the lack of distance between the regulator and the regulated which undermines the willingness of the regulator to impose available sanctions for breach. Of course these enforcement problems may be counterbalanced to some degree by both the positive compliance effects, mentioned above, of 'owning' the regulatory space as well as the precarious nature of self-regulation - if rules are too pro-market and are not enforced, the likelihood increases that the market will lose the regulatory franchise.

\section{Theorizing the Preconditions for Self-REgulation}

We might think about the probability that the market will elect to regulate itself through the lens of the costs (or lost benefits) of failing to do so. Clearly for many market actors there are significant benefits of remaining unregulated. However, market actors will collectively realise that where their actions are generating public and political disquiet, there is a distinct likelihood of state regulatory intervention. Self-regulation in such a context may impose costs on market actors but will be viewed as the lesser of two evils and as way of deflecting political pressures to introduce more costly state regulation. Presented more formally, where $\mathrm{CSR}_{\mathrm{SR}}<\mathrm{CS}_{\mathrm{S}}$ then market actors will enter the 'contracting zone's to produce self-regulation,

\footnotetext{
${ }^{3}$ I am grateful to Michael Klausner for encouraging me to present this analysis through the lens of the contracting zone.
} 
where compared to a state of the world without regulation: $C_{S R}$ equals the costs ${ }^{4}$ for market participants of a self-regulatory regime which they control and enforce plus the transaction costs - the costs of coordination - of agreeing on and maintaining the terms of self-regulation; $\mathrm{C}_{S}$ is the cost of state regulation to the market actors; and $\mathrm{C}_{\mathrm{SR}}$ and $\mathrm{C}_{\mathrm{S}}$ are both discounted for the probability of state intervention. The costs of co-ordination will vary as a function of the homogeneity and proximity of the actors in question. Such homogeneity and proximity are also likely to foster coordination cost reducing norms such as a sense of responsibility for the space within which the activity takes place.

$\mathrm{C}_{S R}$ and $\mathrm{C}_{S}$ are individual variables for each player - or category of player - in the marketplace. Where there are multiple categories of player it is possible that whereas $\mathrm{C}_{\mathrm{SR}}<\mathrm{C}_{\mathrm{S}}$ for some categories, $\mathrm{C}_{\mathrm{SR}}>\mathrm{C}_{\mathrm{S}}$ for others. In such circumstances all parties will not be brought into the 'contracting zone' in the absence of either some differential power weighting for key actors for whom $\mathrm{C}_{\mathrm{SR}}<\mathrm{CS}_{S}$ or a coordinating mechanism that ensures a response where in aggregate $\mathrm{C}_{\mathrm{SR}}<\mathrm{CS}_{\mathrm{S}}$. A similar calculus operates where market actors' concern is not the cost implications of state regulation but the costs implications of the failure to regulate, due to, for example, the political-failures of the executive or legislative authorities that are deadlocked or for other reasons incapable of acting. Here participants will, optimally, enter the contracting zone where the aggregate benefits of selfregulation, $\mathrm{B}_{\mathrm{SR}}$, exceed the transaction costs of coordination. Although again, individual variation in $\mathrm{B}_{\mathrm{SR}}$ may impede parties entering the contracting zone.

\section{Figure 1: Contracting Zone Open:5}

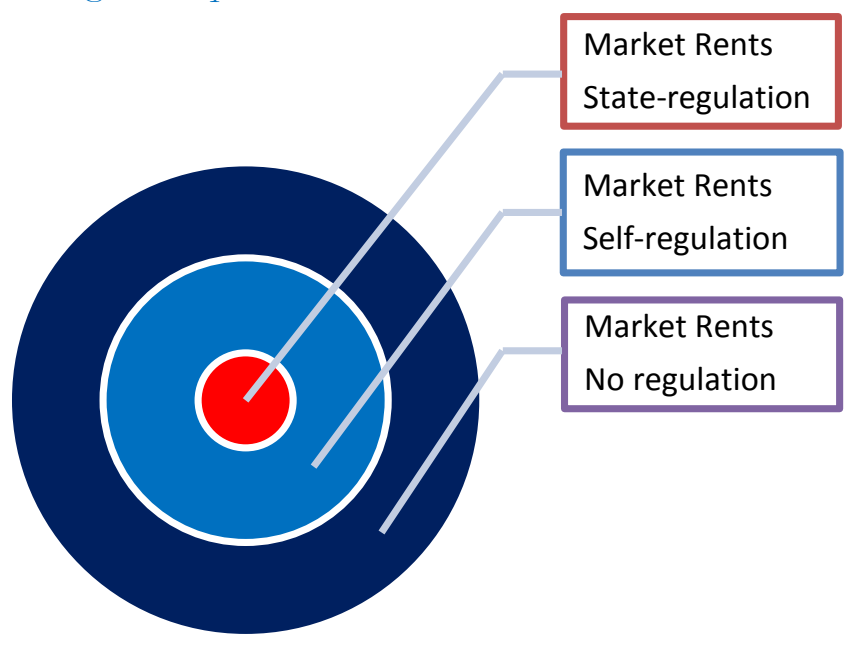

\footnotetext{
${ }^{4}$ If $\mathrm{C}$ represents benefits and not costs then the inequality is reversed for market participants to enter the contracting zone: $\mathrm{C}^{\mathrm{SR}}>\mathrm{C}^{\mathrm{S}}$.

5 These diagrams address $\mathrm{C}_{\mathrm{SR}}><\mathrm{C}_{\mathrm{S}}$ not $\mathrm{B}_{\mathrm{SR}}<>0$.
} 
Figure 2: Contracting Zone Closed:

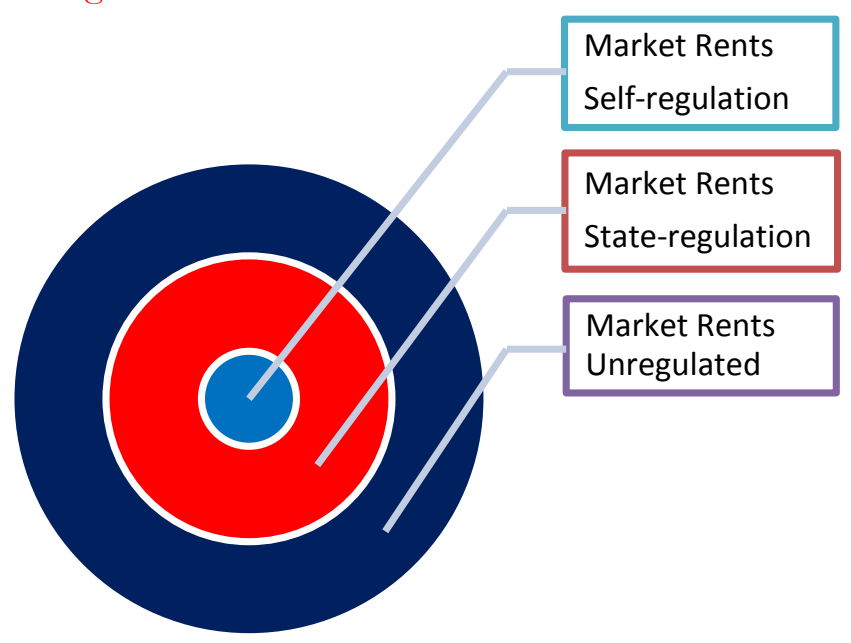

It is plausible that such a cost calculus is an important component of the drivers of the real world examples of self-regulation. However, it is most certainly a secondary driver. Whether actors can enter the contracting zone is a function of whether the state will countenance self-regulation. In an idealised world if the state acts as a rational actor, whether it would permit self-regulation would be a function of an assessment of the the costs and benefits of self- and stateregulation, outlined in Section 1 above, as applied to the particular regulatory context. Where the social welfare benefits of self-regulation exceed those of state regulation one would expect a rational state to permit or to facilitate self-regulation and where they do not to pre-empt self-regulatory contracting.

Figure 3: Contracting Zone Open:

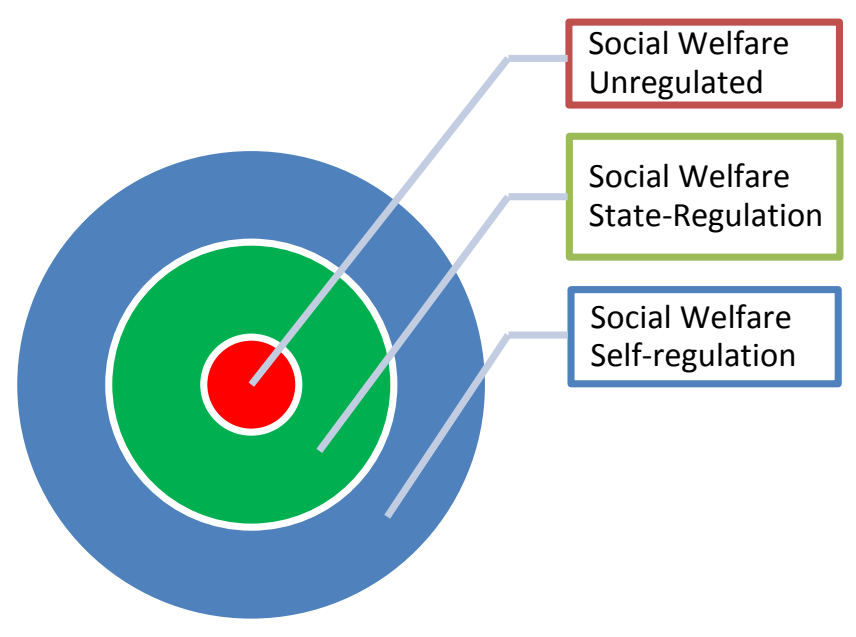




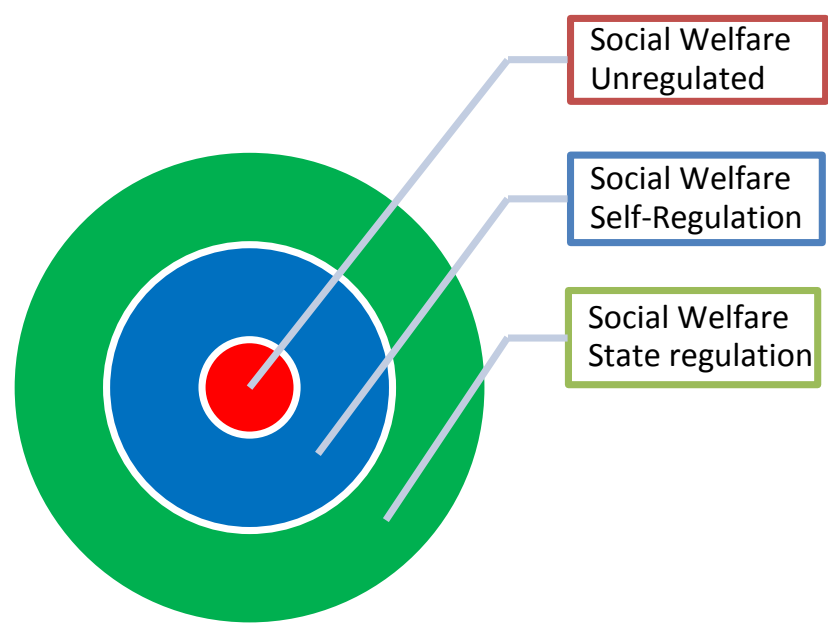

But clearly, the willingness of the state to open the contracting zone is a function of more than such a calculus. Of central importance in this regard is the regulatory conception of the state and whether such a conception countenances or encourages self-regulation. By regulatory conception of the state I mean the shared understanding - amongst politicians, market actors and citizens more broadly about the extent to which it is legitimate or illegitimate for the state to exercise power to identify and address problems generated by interactions within civil society; or, put differently, legitimate or illegitimate for non-state actors to perform regulatory, state-like functions. Where this regulatory conception of the state does not countenance self-regulation, even where Figures 1 and 3 apply, there is no scope for the market place to legitimately occupy the regulatory space policed by the state and therefore no scope for there to be a 'contracting zone' within which the market actors' cost calculus could operate. In such a context market actors are left to try and coordinate improved behaviour in the hope of dampening political concern, or, where the problem is the failure of the state to act, to lobby for state action. Where the conception of the state is open to, or favourable to, marketbased action then the contracting zone comes into play. It is for this reason that it is unsurprising that we find that many of the examples of corporate self-regulation - some of which are discussed in this chapter - are produced in the United Kingdom, a jurisdiction that for several centuries actively promoted local and market-based solutions to identified problems. An approach that resulted from a longstanding and deeply held 'wariness towards the central state apparatus'.6

\footnotetext{
6 See generally, Alan Fox, History and Heritage: The Social Origins of the British Industrial ReLATIONS System (1988). I am very grateful to Paul Davies for recommending to me that I consider the theory of state set forth in this wonderful text.
} 
There is a significant body of scholarship on the passive conception of the UK state which we can only touch in here. Jenks, for example, contrasts the prevailing political style in nineteenth and twentieth century Britain with the 'imaginative conception of politics' associated with the utilitarianism of Bentham and John Stuart Mill. ${ }^{7}$ For Jenks, this utilitarian conception of politics involved an active form of government: 'a conception of problem solving and exploration of opportunities for innovation as the very stuff of politics'. The British political style and the conception of the state that underpinned it was the antithesis of such an active and interventionist style. For Jenks, the British approach is characterised by sobriety, neutrality and a resistance to problem solving, almost a willed passivity in the face of identified problems until faced with no alternative but to act. In his seminal work on the history of industrial relations in the UK Alan Fox observes that as 'it was not part of the state's duty to anticipate and meet needs which seemed likely to grow'; the problem would have to grow 'to a major size before the government decided to step in'. But as the great labour lawyer Otto Kahn-Freund observed, the resistance to proactive intervention and directed control should not be mistaken for the absence of any form of intervention or role for law. For Kahn-Freund, in the UK there was widespread support for the 'social institution' of 'organized persuasion' where the state's, and law's, role was to facilitate parties in creating order, reaching agreement and resolving conflict. ${ }^{8}$ At most, Government's role was to take steps - from cajoling actors to respond, to the creation of institutional structures - that would facilitate actors in addressing the problem themselves. The bedfellow of this political outlook was an expectation, and sense of entitlement, that market actors themselves should be given an opportunity to address identified problems themselves. For politicians, an electoral minefield awaited those who proactively disturbed those expectations, and accordingly 'crisis dimensions' were required to drive government to [directly] intervene. ${ }^{9}$

This conception of the British State helps understand why, until the latter part of the twentieth century, in the UK there was no form of what today we would recognise as capital market or banking regulation, responsibility for which was left to the City of London and the City's 'Pope',10 the Governor of the Bank of England, a non-state body itself until 1947. An approach which led Louis Loss in his treatise on US Securities Regulation to observe that it was paradoxical that the US 'the arch apostles of private enterprise should have resorted to public control

\footnotetext{
${ }^{7}$ Craig Jenks, T.H. Green, The Oxford Philosophy of Duty and the English Middle Class (1977) 28 BRITISH JOURNAL OF SOCIOLOGY 481, 494.

8 Otto Kahn-Freund, Industrial Relations and the Law - retrospect and prospect, 7 BRITISH JOURNAL OF INDUSTRIAL RELATIONS 301 (1969).

${ }^{9}$ Fox supra note 6, 374.

10 Sir Leslie warns on the Takeover Code, (16 August, 1968 THE GUARDIAN). A different metaphor used in relation to the Bank of England was the Bank as 'parent'. Harry Siepmann of Lazards referred to the 'faith in the Bank as the Leader and Parent of the City' (David Kynaston, The City of London: A Club No More (2002), 57.
} 
while socialist Britain...should have left so wide a field free from state control'.11 This conception also helps explain why the UK did not have a developed system of industrial relations or labour law until well into the 1970s. A regulatory lacunae that was viewed as a mark of success not state failure. Alan Fox observes in this regard that in as late as the early 1960s:

The industrial relations systems of less 'mature' capitalisms such as the United States and Germany were thought to reveal their immaturity by their heavy dependence on legal definitions and sanctions and on their being more consciously and deliberately designed by the state. ${ }^{12}$

Whilst one can chart a retreat from, or the disintegration of, this conception during the post-World War II period, and in a more pronounced way in past 40 years, many of the classic examples of corporate and non-corporate self-regulation in the UK, are in large part a product of this conception and, as we shall see below, its mark is still impressed on contemporary self- and market controlled UK approaches to the regulation of the corporation. In other jurisdictions, including twentieth century United States and other European jurisdictions, where the conception of the regulatory state more closely approximates Jenk's utilitarian conception of politics, ${ }^{13}$ the scope for market players to take control of the regulatory space and enter the contracting zone was much more attenuated. Unsurprisingly, in such jurisdictions examples of self-regulation are much less prevalent.

Where the conception of the state does enable self-regulation, the activity that takes place within the 'contracting zone' must be framed through a continuing relationship of the state to the contracting market actors. We have already noted the role of possible state intervention in incentivizing actors to enter the contracting zone - the threat to act if the market fails to do so. Moreover, the long-term success and stability of any self-regulatory response is dependent upon it maintaining its (democratic) legitimacy in the eyes of the public and the state. In particular, as the self-regulator usurps the regulatory function of the state it must be seen to do so in an unbiased and even-handed way. Arguably, this need to maintain legitimacy renders self-regulation unstable, if not unworkable, in the long run in contexts where due to knowledge and information asymmetries it is difficult for the state to assess whether or not the self-regulator is acting in a neutral or unbiased fashion. Visible failures in that market place are likely to lead to the

\footnotetext{
11 See L.C.B. Gower, Investor Protection in the US A, 15 MODERN LAw REVIEW 446, 447 (1952).

${ }^{12}$ Fox, supra note 6.

13 Clearly this chapter cannot undertake a broad ranging comparative analysis of the conceptions of the regulatory state in US and European jurisdictions. But in support of this claim consider, and compare, for example, the mid-20 $0^{\text {th }}$ century UK approach to the regulation of financial markers, corporate law, antitrust and labour law with the evolution of US federal securities regulation (Gower, supra note 11), antitrust regulation, corporate law (see David Kershaw, The Path of Corporate Fiduciary Law, 8 NYU JOURNAL OF LAW AND Business 395 (2012) and labour law (see generally ALAN Fox, supra note 6).
} 
inference of self-regulatory failure. Even if such an inference is inaccurate, the knowledge and information asymmetries make it very difficult to explain to the regulator, or the public, why it is inaccurate. In these contexts, such failures may in of themselves irretrievably de-legitimise the self-regulator regardless of any failing or fault on its part.

\section{MARKET-CONTROLLED REgULATION}

Everyone wants the best of both worlds. But invariably the real world consists of second best solutions that make inevitable trade-offs between the 'bests' of each world. The above analysis has identified several advantages of self-regulation but also several bias, enforcement and stability problems. Would it be possible to devise a system of corporate regulation that gets the upside of self-regulation but minimises the downside? For the state to demarcate the contours of regulation, but to command the market to fill in the substantive content of that regulation? That is, is it possible to leverage the advantages of self-regulation in rule production - in particular the markets' knowledge and information advantages whilst at the same time maintaining formal state oversight of the regulation? We might describe this approach to corporate regulation as forced self-regulation or 'market-controlled regulation'.

Typically in the corporate law and governance space this takes place through a legal or regulatory requirement to comply with or to take account of rules produced by market actors. Corporate governance codes provide perhaps the best example of this where legislation or regulation in several jurisdictions provides that companies must comply or explain their failure to comply with the rules produced by a designated governance body or commission. ${ }^{14}$ These bodies are usually hybrid state/market regulator staffed by market participants but with some formal connection to the state. We explore this form of market-controlled regulation in Part IV of this chapter.

\footnotetext{
14 The German Corporate Governance Code is not part of The German Stock Corporation АСт but the requirement for publicly traded German Stock Corporations to comply with or to explain the failure to comply with its provisions are set forth in section 161 of the German Stock Corporation Law. The Code is produced by a Government appointed commission. Similarly, ThE UK CORPORATE GOVERNANCE CODE although maintained by a quasi-state body, the FRC, benefits from a mandatory requirement in the UK Financial Conduct Authority's Listing Rules to comply or explain non-compliance with the Governance Code (LR 9.8.6(5)). Across the Atlantic, the Governance rules set forth in the New York Stock Exchange are the product of a self-regulatory organisation, but SRO's are authorised by the SEC and their rules, including the governance rules are subject to SEC oversight and approval (see section 19 Securities and Exchange Act of 1934).
} 


\section{III. 'ENDOGENOUS' SELF-REGULATION: A TAKEOVER CASE STUDY IN THE UK AND BRAZIL}

Examples of successful self-regulatory regimes that regulate significant parts of corporate activity and that have no formal connection to the state are rare. The most notable example is the UK's Takeover Code and the Takeover Panel which enforces and maintains the Code. The Code provides an extremely comprehensive body of rules regulating all aspects of the takeover process for publicly traded companies. The Takeover Panel is globally recognised as one of the most powerful and effective command and control regulators. Yet between 1968 and 2005 when it became a state regulator as a result on the implementation of the EU's Takeover Directive ${ }^{15}$ - this was achieved without direct instruction from, or empowerment by, legislation or regulation.

The first attempt to regulate the UK takeover market followed political and media disquiet which arose in the 1950s as a result of target companies using takeover defences, including a crown jewel defence in the battle for the Savoy Hotel and a white squire share issue defence in the battle for British Aluminium. ${ }^{16}$ These actions generated multi-facetted political and public concerns from which one would be hard pressed to identify a dominant concern. ${ }^{17}$ The concerns included: disapproval of hostile bids as an inappropriate interference in the "corporate bastion"; 18 concern about the ethics of the takeover market place; ${ }^{19}$ anxiety about the effects of hostile activity on economic policy commitments to restrict income inflation; 20 and concerns about illegitimate board interference in shareholder sovereignty. ${ }^{21}$ In July 1959 this led the Bank of England, which at the time was solely responsible for 'regulating'22 banking and capital markets in the UK, to form a working group consisting of participants in the UK capital markets in order to produce a Code of Conduct to regulate hostile and competitive bids.

\footnotetext{
15 EU Directive 2004/25/EC.

${ }^{16}$ The two key events were the attempted takeover of the Savoy Hotel which involved a lock-up of its key asset, the Berkley Hotel and the battle for British Aluminium. In relation to which see Richard Roberts, Regulatory Responses to the Rise of the Market for Corporate Control in Britain in the 1950s (1992) 34 BUSINESS HISTORY 183, 187.

17 See David Kershaw, Foundations and Principles of Takeover Regulation (2015, forthcoming) chapter 3 (on file with the author).

18 Kynaston, supra note 10 in his magisterial history of the City of London notes in relation the British Aluminium takeover battle discussed below the 'entrenched belief that within its citadel, the board knew best'(at 112) .

${ }_{19}$ A note by Maudling, Economic Secretary to the Treasury, for the Prime Minister (Winston Churchill), observed that, although nothing could be done, 'the process is distasteful and politically embarrassing' Pro, PREM/656, Letter from the Economic Secretary to the Treasury to the Prime Minister, 13 November 1953 (quoted in ROBERTS, supra note 16, 183, 188).

${ }^{20}$ See RoBerts, supra, at note 15.

${ }^{21}$ See 'Directors Duties' Financial Times (8 December 1953).

22 Regulation in this context would be a misnomer as banks and capital markets actors were regulated by the Bank of England through direct supervision and what is sometimes referred to as a regime of nods and winks - see KYNASTON, supra note 10 at 562.
} 
Importantly, UK merchant (investment) banks - through their trade association the Issuing Houses Association - took control of the production of this Code of Conduct. They produced their own working party which was tasked with producing an initial draft code. ${ }^{23}$ Other market constituencies clearly had input into this process although it was reported that that there was 'general agreement about the principles involved'. ${ }^{24}$ The resulting Code of Conduct, which came into force in 1959, was cumbersomely named the 'Notes on the Amalgamation of British Business'. However, the Code was wholly unsuccessful and did not generate behavioural constraint in the UK takeover market. From the moment it was published it was clear that it would not constrain behaviour when an actor's interest diverged from the rules. There was no body responsible for updating and enforcing the Notes and although the Notes contained the structural and substantive seeds of modern takeover regulation, in many instances they were comically ambiguous: For example: 'every effort' should be made to avoid market disturbance; shareholders should be given 'adequate time (say three weeks) for accepting' the offer; and it was 'desirable' that the offer is for the whole share capital. It was, therefore, unsurprisingly that the market place ignored the Notes in multiple ways, ${ }^{25}$ including the replication of the very events that led to the Notes on the Amalgamation of Business. For example, in the1967 battle for Cook \& Watts Ltd the target board locked-up a deal with its preferred bidder by agreeing to issue a majority of the company's ordinary shares in exchange for the sale of one of the preferred bidder's subsidiaries. ${ }^{26}$ Similarly, later in the same year in relation to a hostile bid for Metal Industries, the target again agreed to issue a block of shares in exchange for the sale of the preferred bidder's subsidiary. ${ }^{27}$ These events generated renewed political and media clamour for regulatory intervention and again resulted in the Bank of England bringing market participants together to put their own house in order. ${ }^{28}$ For the first time the group included representatives of management. Again the merchant banks through the Issuing Houses Association took the lead in revising the Code. A subcommittee was created to revise the Notes, which 'did most of the work and the drafting of the code' and consisted only of Issuing House Association representatives from four merchant banks, one of whom, Robert Clark, had

\footnotetext{
23 See 'City Views on Take-Over Bids' (31 October 1959) FinAnCial Times observing that the Notes were 'prepared by the Issuing Houses Association in co-operation with' the other working group members" (emphasis supplied). Roberts reports that the original draft of the Code was produced by its Chairman J.S. French who was a director of the Issuing House London and Yorkshire Trust (supra note 16, at 195). ${ }^{24} \mathrm{Id}$.

${ }^{25}$ See, for example, Phillips' takeover of Pye in January of 1967 'Explanation of share transactions' (26 January 1967) FinANCIAL TimeS and the battle for Wilkinson \& Ridell ('Behind the scenes of the Wilkinson \& Ridell Battle' (29 June 1967) FINANCIAL TimES. Both involving favourable treatment for institutional shareholders.

26 'Courtaulds wins Cook' (28 April 1967) THE GuARDian.

27 '"Outrageous" and Sir Jules puts Thorn back in the battle' (17 July 1967) THE Guardian.

${ }^{28}$ See John Armour and David Skeel's careful documentation of this process and the resulting creation, at the end of the 1960s, of the City Code on Takeovers and Mergers and its enforcer, the Takeover Panel (John Armour and David Skeel, Who Writes the Rules for Hostile Takoevers and Why? - Peculiar Divergence of US and UK Takeover Regulation 95 GEORGETOWN LAW JOURNAL 1727 (2097)).
} 
previously been a partner at Slaughter and May, the leading City law firm. ${ }^{29}$ The result was the newly named Takeover Code which, building on the Notes, provided a pro-shareholder code that directly responded to the problematic events that generated pressure for action and, of some contextual importance, was wholly in keeping with the pro-shareholder orientation of UK company law. Furthermore, the City provided for a self-regulatory body, staffed by representatives of market participants to administer the Code.

Today's Takeover Code provides for a set of extremely demanding rules as well as a feared and uncompromisingly independent regulator. Compared to the Takeover Code - which today amounts to 300 pages of rules and rule-guidance other jurisdictions' takeover rules, for example the US's Williams Act, appear rather insubstantial, perhaps incomplete, ${ }^{30}$ and are much more deferential to the parties' freedom to contract. In addition to the well-known non-frustration rule preventing any target board frustrating action, ${ }^{31}$ and the mandatory bid rules triggered when crossing the $30 \%$ threshold or further purchases within the 30 $50 \%$ ownership range, 32 the Code provides many other highly interventionist and controlling rules. For example, the Code requires announcements of possible offers when there is any untoward movement in the share price ${ }^{33}$ - what amounts to untoward is determined by the Panel. In contrast to the Williams Act ${ }^{34}$ in the United States - which provides for an all-holders-best-price rule which applies only during the bid period and only in relation to one class of shares - the Takeover Code requires bids for all share classes and convertibles ${ }^{35}$ and provides for an equal pricing rule both during the bid and between three-twelve months prior to the bid. ${ }^{36}$ The Code provides for what is known as a put-up or shut-up rule requiring the bidder to make an announcement of a firm offer 28 days following an announcement of a possible offer. ${ }^{37}$ An announcement of a firm offer as well as the offer itself may only be subject to limited conditionality which is controlled by the Panel. ${ }^{38}$ It is the Panel not the parties or a court that, for example, determines whether a material adverse change clause can be called. Finally, and perhaps most surprising for a US audience, the Code has long placed significant constraints on the use of deal protections including break-fees. Until

\footnotetext{
29 The members of the subcommittee were: Michael Bucks (Chairman) (Rothchilds); Robert Clark (Hill Samuel); Ken Barrington (Morgan Grenfell); Peter Cannon (Minster Trust - "an upstart finance house" 'The men behind the Code' (27 March 1968) FinANCIAL Times.

30 Of course in considering the completeness of US takeover process regulation one needs to take account of the indirect process effects of the availability of takeover defences subject to state corporate law.

31 Rule 21 Takeover Code.

32 Rule 9 Takeover Code.

33 Rules 2.4 Takeover Code

34 Regulation 14D, Rule 14D-10

35 Rules 14-15 Takeover Code.

36 See Rule 6, 9 and 11 Takeover Code.

37 Rule 2.6 Takeover Code.

38 Rules 12 and 13 Takeover Code.
} 
2011 a break-fee could not exceed one percent of deal value. After 2011, save in limited circumstances, they are prohibited altogether. ${ }^{39}$

The Takeover Panel today is a state body. Pursuant to the Companies Act 2006, which implemented the European Takeover Directive, the Panel is a 'recognised supervisory authority'. ${ }^{40}$ As a state body the Takeover Panel now has clear access to the power of the state to sanction Code transgressions. ${ }^{41}$ It is noteworthy that from the 1980s the Takeover Panel had theoretical access to the enforcement powers of the UK capital market regulators. And from its inception it had access to licensing sanctions in relation to certain market participants that were regulated by the Board of Trade, a government department. But these trappings of state power are of no relevance to the success of this endogenous self-regulatory body. They have never, and are highly unlikely to ever, be used. If the probability of Code compliance were a function of the probability of the use of some form of state power to enforce the Code, then there would be no compliance with the Code because the probability of the use of state power is zero. Yet there is close to total compliance with the Code; and incontrovertible deference to the views and instructions of the Panel. What then explains the success of this self-regulatory mechanism and what are the preconditions to replicating its success? These are important questions of contemporary relevance both generally to the question of in what circumstances, if any, can self-regulation be effectively deployed within corporate law, but also of specific importance to takeover regulation in other jurisdictions, such as Brazil, who are currently experimenting with similar forms of self-regulation often because vested interests or governance failures are thought to prevent the state from regulating directly and effectively. ${ }^{42}$

Based on the experience of the Takeover Panel and Code, below I suggest five key drivers to the successful self-regulation of the market for corporate control. A set of drivers that suggest that the Takeover Panel's existence and success is sui generis and that successful replication in other jurisdictions is improbable.

\section{The Deferential State}

The Takeover Code and the Takeover Panel are the product of the mid-twentieth century conception of the British state which, as detailed in the Introduction above, contained an inbuilt assumption of state passivity. This lens generated a regulatory logic which viewed the UK state's role as one of facilitating and organizing selfregulatory solutions. This conception did not merely generate space for the 'contracting zone', it actively encouraged entry by market participants. Consider,

\footnotetext{
39 Rule 21.2 Takeover Code.

40 Section 942 Companies Act 2006.

${ }^{41}$ See sections 952-956 Companies Act 2006.

${ }^{42}$ See generally, Henry Hansmann, Ronald J. Gilson, Mariana Pargendler, Regulatory Dualism as Development Strategy: Corporate Reform in Brazil, the US and the EU 123 YALE LAW JOURNAL 948 (2014).
} 
for example, the UK Government's sense of powerlessness in relation to the Battle for British Aluminium. Kynaston notes in this regard that the Prime Minister's (Harold Macmillan's) view was that 'it would be a grave political error to interfere now $[\ldots]$ Let the rival forces fight it out [...] It's the only safe course'.43 Self-regulation of the takeover market in the UK is often presented as political disarmament: the powerful state threatens to act which leads market actors to selfregulate their activity in order to deflect intervention. This is invariably a key factor in driving what appear to be self-regulatory solutions. And this lens certainly animated many actors and commentators around the time of the formation of the Code and the Panel. ${ }^{44}$ But this lens must be placed within the context of this then prevailing conception of the British state which created a presumption and an expectation - firmly held within government, the City of London and the Bank of England - that market participants should address and resolve the problems of their own making. State intervention in the market for corporate control in the UK at the end of the 1950s and 1960s would have represented a regulatory paradigm fissure. Publicly stated fears and threats of intervention must accordingly be discounted to take cognisance of this conception. Consider in this regard the Financial Times' LEX column on July of 1967 that called both for more precise rules and a means of enforcement in light of the multiple high profile takeover 'scandals' of that year. It noted the concern that if the issues were not addressed by the City then Government may be forced to step in. 45 A concern that was repeated in the press and crystallised around an idea of the threat of a British Securities and Exchange Commission (SEC). ${ }^{46}$ In spite of this perceived looming 'threat', in fact consistent with the longstanding British regulatory style, the Government, the media and the City, were all of the view that the takeover problem was presumptively a problem for the City to solve. Less than a week later in his Mansion House speech the Prime Minister, Harold Wilson, echoed the FT's sentiments but observed that 'it is for the City to ensure that these processes are and are seen to be, carried through in accordance with clearly formulated rules'. Of course, if the City failed to act there remained a threat of Government intervention and certainly by the late 1960s this threat was increasing as more commentators called for a break with tradition and greater state involvement in the regulation of business. ${ }^{47}$ But given the continuing weight of presumption

\footnotetext{
${ }^{43}$ Kynaston, supra note 10, 114.

44 'What the new bid panel needs to do’ LEX, (21 September 1967) FinAnCial Times.

${ }^{45} \mathrm{Id}$.

46 'What the new bid panel needs to do' LEX, (21 September 1967) FinanCial Times.

${ }^{47}$ In 1969 (see supra note 8) Otto Kahn-Freund argued in the context of industrial relations that the law 'should be called upon to play a much increased role in the moulding of industrial relations, and this in a manner that is contrary to a long established tradition, a tradition, however, that is beginning to fade'. Although beginning to fade it remained a forceful lens. Consider, for example, the Royal Commission on Trade Unions and Employee Associations, the Donovan Commission, was set up in the mid-1960s to consider labour relations and collective bargaining problems. Several of the recommendations involved direct legal intervention. However, importantly, the primary innovation recommended by the Donovan Commission, and subsequently adopted by the Labour Government in its 1969 White Paper, IN PLACE OF STRIFE,
} 
associated with the British approach to governance, the probability of intervention at this point was still extremely low. Historically situated, governmental concerns and media attention were communicative triggers to tell the City to organise itself to address the concerns that had arisen in relation to takeovers.

The centrality of this conception of the state to the UK takeover regulation story suggests that this form of corporate self-regulation is sui-generis. In the absence of a similar conception, the contracting zone may be locked as selfregulation is viewed as an illegitimate intrusion into the role of the state; an antidemocratic grab for state authority. Moreover, this sense of illegitimate intrusion is likely to be compounded in more modern regulatory settings for capital markets, which typically already provide for a capital markets regulator who would be viewed as the natural regulator for such a new regulatory venture and who is likely to make a territorial claim thereover. In the United States context, for example, at the time of the introduction of the Williams' Act the pre-existence of the SEC generated a path dependent preference to address takeovers through an expanded SEC jurisdiction. ${ }^{48}$ This factor is of particular concern in relation to modern attempts to replicate the Takeover Code's self-regulatory success. Brazil has been much lauded for its regulatory dualism which involves the introduction of alternative regulatory regimes designed to offer companies and shareholders, at their election, protections that the state has failed to offer. ${ }^{49}$ In this vein of regulatory dualism, a body of market constituents has recently come together in Brazil to produce a self-designated Committee on Mergers and Acquisitions (CAF). ${ }^{50}$ The CAF Code describes the body as 'a non-statutory independent body created by representatives from the main Brazilian capital market players to operate on the basis of a voluntary self-regulation model'. ${ }^{51}$ It provides takeover regulation to companies that elect to be bound by its rules. ${ }^{52}$ Although this author is in no position to provide any account of the contemporary conception of the Brazilian state, and whether or not it is similarly open to endogenous self-regulatory initiatives, it is clear that attempts to generate space for this regulatory solution have generated difficulties in traversing the territorial authority of the existing Brazilian Capital Markets regulator, CVM. In this regard, it is noteworthy that the Code itself observes that it 'should not be regarded as a substitute' for either law or CVM. ${ }^{53}$ That is, there is a pre-existing occupant of this regulatory space, even if

\footnotetext{
involved the setting up of a Commission on Industrial Relations, a body staffed with non-governmental members from unions, business and academia. The Commission ${ }^{47}$ was designed to facilitate the voluntary reform of the collective bargaining system; this was 'organized persuasion' par excellence.

48 John Armour \& David Skeel, Who Writes the Rules for Hostile Takeovers and Why 95 GEORGETOWn LAw JOURNAL 1727, 1776-1785 (2007) detailing the centrality of the SEC to the US regulatory response to takeover concerns in the 1960s.

${ }^{49}$ See Hansmann et al supra note 41

${ }^{50} \mathrm{CAF}$ stands for Comitê de Aquisições e Fusões. See: http://www.cafbrasil.org.br/eng/index.html.

${ }^{51}$ CAF Code, Introduction, 1.

52 See CAF Code, Introduction, 3. Companies sign up by amending the subject company's bylaws to provide that they are subject to the Code. In addition directors, officers and controlling shareholders sign "statements of adherence" to the Code.

${ }^{53}$ CAF Code, Introduction, 1 (iii).
} 
- to carry the occupation metaphor further - they have been neglecting their property.

\section{All For one AND ONE FOR ALl: Rules Trade-OfFs AND COORDINATING MECHANISMS}

Provided the contracting zone is open, it is necessary to get the affected market actors to the contracting table. The first UK Takeover Code acknowledged the importance of buy-in from all parties. In a statement issued shortly after its formation the Panel referred to the importance that the 'voluntary system should function effectively and command the respect of all'.54 If key players opt-out then there can be no self-regulatory solution. As noted above, the cost calculus for market actors will vary for different parties with both $\mathrm{C}_{\mathrm{SR}}<$ and $>\mathrm{C}_{\mathrm{S}}$ and $\mathrm{B}_{\mathrm{SR}}<$ and $>0$ for different participants. There are two key considerations for successfully getting parties into the contracting zone. First, as $\mathrm{B}_{\mathrm{SR}}$ and $\mathrm{C}_{S R}$ will be, inter alia, a function of the selected self-regulatory rule choices compromises will have to be made to ensure that rule choices are not made that render $\mathrm{B}_{\mathrm{SR}}<0$ or $\mathrm{C}_{\mathrm{SR}}>\mathrm{C}_{\mathrm{S}}$ for key players. In addition, but also as a substitute for such rule tradeoffs, contracting is more likely to take place where there are co-ordinating mechanisms in place that either force contracting or the reduce the co-ordination costs of contracting.

Let us consider first the relationship between rule choice and variation in relation $\mathrm{B}_{\mathrm{SR}}$. If the rule makers reject the basic economic logic that key players will not contract if $\mathrm{B}_{\mathrm{SR}}<0$, the self-regulatory venture is likely to fail. This logic and lesson does not bode well for Brazil's attempt to generate self-regulatory dualism in the takeover field. CAF has the support of several constituents of the Brazilian Capital Market including: the Brazilian Securities Exchange (BM\&FBOVESPA S.A. -Bolsa de Valores, Mercadorias e Futuros, 'BVMF'); the Association of Capital Markets Investors (Associação de Investidores no Mercado de Capitais; 'AMEC'); the Brazilian Association of Entities of the Financial and Capital Markets (Associação Brasileira das Entidades dos Mercados Financeiro e de Capitais, 'ANBIMA'); and the Brazilian Institute of Corporate Governance (Instituto Brasileiro de Governança Corporativa, 'IBGC'). However, the Brazilian Association of Publicly-Held Corporations (Associação Brasileira das Companbias Abertas, 'ABRASCA') did not join the group after a long period of negotiation. The reason for their opt out is thought to be the mandatory bid pricing rule contained in the Code. $55 \mathrm{~A}$ mandatory bid is triggered by a purchase of between $20-30 \%$ of the target's shares (the precise percentage determined by the by-laws). ${ }^{56}$ The mandatory bidder must offer to all shareholders the highest price paid for the shares in the previous

\footnotetext{
54 Panel on Takeovers and Mergers, Policy Statement (28 April, 1969).

55 See CAF Code, Section VI on 'Material Ownership Tender Offers'.

56 See definition of "Material Ownership" in CAF Code.
} 
twelve months. ${ }^{57}$ The rule is understood to further the key takeover regulatory goal of equality of treatment of shareholders. ${ }^{58}$ However, for many large Brazilian companies which are subject to blockholder control, such a rule would prevent a controller from receiving any payment for its private benefits of control as any per share control premium paid to the blockholder within a twelve month look-back period must also be offered to all shareholders. It is a forced sharing rule which, given the consensual nature of Code application, means that blockholder owned public companies are unlikely to sign-up. Nor will their trade association, ABRASCA. Alternative rules would have enabled sign-up by this key constituency: for example, no or a short look-back period would enable premium block purchases which would not be subject to the highest price rule; or a weighted pricing rule taking a percentage of the highest price paid. Of course, even in the absence of widespread sign-up by public companies, from a regulatory dualism perspective the Code still offers benefits to existing widely-held companies - as well as companies that intend to effect an IPO where there will be no post-IPO controller - allowing them to elect to lock-in ${ }^{59}$ the sharing rule which many minority shareholders would value. Nevertheless, rule integrity here appears to jeopardise generating momentum for the project. What is driving this counterproductive rule-choice is difficult to parse. But it seems plausible that a possible driver is a classic translation problem: the desire of cosmopolitan legal elites to replicate, and to find authority for legal change in, foreign 'best practice' regulation ${ }^{60}$ - here in relation to the perceived importance of the equality of treatment of shareholders - at the expense of pragmatic adaptation to the conditions of the local market place. It is noteworthy in this regard that by the time the UK adopted a twelve month sharing rule for the mandatory bid rule in the mid-1970s there had been a significant reduction in the number of controlling shareholders in publicly traded companies and a concomitant increase in institutional holdings. ${ }^{61}$

Where parties refuse to enter or reach agreement within the contracting zone, optimal welfare enhancing solutions - for the state and aggregate market actors may be left on the table. In such circumstances coordination mechanisms are required to enable self-regulation. The story of the Takeover Code in this regard directs us to the importance of the financial incentives of pivotal players for coordinating self-regulatory contracting. Most important in this regard were the financial incentives of merchant (investment) banks. Prior to the Battle for British Aluminium, UK merchants banks were almost exclusively pro-management. ${ }^{62}$ The seismic cultural shock which resulted from the failure of the target to succeed in

\footnotetext{
57 Article 65(1) CAFCode.

58 Article 29(1) CAF Code.

${ }^{59}$ Lock in here is somewhat limited given to option of exit from the Code following a one year notice period. See CAF Code, Articles 23-25.

60 See generally William Ewald, Comparative Legal Jurisprudence (II): The Logic of Legal Transplants 43 THE AMERICAN JOURNAL OF COMPARATIVE LAW 489 discussing the work of Alan Watson on legal transplants. 61 See Brian R. CheFFins Corporate Ownership and Control (2008) 301-377.

${ }^{62}$ KYNASTON, supra note 10 at Chapter 6.
} 
this case led bankers to realise that their business model had to adapt to take account of the fact that there was money to be made in hostile activity. 'Overnight', Roberts observes, City attitudes to takeovers changed and 'financial advisors added hostile bids to their repertoire of merger and acquisition techniques'.63 Bankers came to realise that there was money to be made in an active takeover market and in regulation that wedded takeover activity to the financial advisory role. These investment bankers were at the centre of a network of advisory services, many of which were essential components in making a takeover bid. Accordingly, once the market place incentivised bankers to come into the contracting zone many others had no choice but to follow.

Plausibly, such an investment banker driven co-ordinating mechanism could act as a substitute for the absence of state or quasi-state drivers, as is the case in Brazil. However, for two reasons such replication is improbable. First, such an option is only available where hostile activity levels are sufficient to encourage bankers to take a more neutral stance between targets and acquirers. Where controlling ownership structures block a significant increase in such activity levels, as they do in Brazil, investment banker buy-in is likely to be difficult. Secondly, although investment bankers co-ordinated self-regulation in the UK, it was not an endogenous market response. Although co-ordinated action was in the bankers' interests and co-ordination costs for bankers were low - given pre-existing structures for collective action ${ }^{64}$ and the close, geographically proximate and relatively homogenous environment which was the Squire Mile of the City of London at this point in time ${ }^{65}$ - bankers faced a prisoners dilemma coordination problem between 1959 and the introduction of the Notes and the creation of the Code and Panel. Although it was in the long term financial interests of bankers (individually and collectively) to control a regulatory system that put them at the heart of the process, in the immediate term in the absence of such a system it was in the individual bankers' interests to serve their client's needs by facilitating creative (non-) compliance with the Notes. This they did in multiple high profile events. ${ }^{66}$ What was required - and what was in the bankers' individual and collective long term interests - was forced co-ordination, which arose indirectly from state expectation in response these events and directly from the Bank of England, who during this period remained the self-styled 'Pope' ${ }^{67}$ of the City. ${ }^{68}$ In other jurisdictions, in the absence of such direct or indirect state pressure - which

\footnotetext{
${ }^{63}$ Roberts supra note 16 at 193 . See also Armour \& Skeel, supra note 47 at 1775 also observing that 'there was plenty of money to be made on advising on acquisitions'.

${ }^{64}$ The Issuing Houses Association and the Accepting Houses Association.

65 See generally Armour \& Skeel, supra note 47.

66 See supra notes $24-26$ and infra note 73.

67 Sir Leslie warns on the Takeover Code, (16 August, 1968) THE GuARdian. A different metaphor used in relation to the Bank of England was the Bank as 'parent'. Harry Siepmann, Lazards: 'faith in the Bank as the Leader and Parent of the City [...]' (KYNASTON, supra note 10, 57).

${ }^{68}$ Importantly the Bank of England was also strongly incentivised to ensure City co-ordination as any state interference in this zone would have represented a significant loss of authority, at a time when its authority was increasingly being questioned. See, generally, KYNASTON supra note 10, Chapter 6.
} 
is necessarily the case where self-regulation responds to state governance failures this financial advisor co-ordinating mechanism is unlikely to be triggered. ${ }^{69}$

Of course other market actors could also be incentivised to perform the coordinating role, even if no other constituency is as central to the deal process as the financial advisor. In an important article addressing the UK takeover context, Professors Armour and Skeel identify institutional shareholders as a co-ordinating mechanism. For Armour and Skeel, the increasing presence of institutional shareholders in the UK market place in the 1950s and $60 \mathrm{~s}^{70}$ meant that it was in their interests to drive the market's response to exert influence over rule-choice even where it may not have been in individual institutions interests to co-ordinate to monitor individual companies. ${ }^{71}$ In theory, with their increasing presence and power it seems very plausible that institutions could perform the role of selfregulatory co-ordinator in order to generate rules that favour their long term interests. It would follow that the increasing institutionalisation of corporate ownership in a jurisdiction may lead to an increase in the probability that selfregulatory solutions to corporate problems, will arise where the regulatory space has not already been occupied by the state. In this regard, Armour and Skeel suggest that:

It is not surprising that the emergence of a pro-shareholder approach to takeover regulation coincided with the emergence of institutional investors as a significant force in British share ownership.

With regard to the UK, Armour and Skeel are clearly correct that the 'emergence of institutional investors' played a key role in creating the conditions within which the self-regulation of takeovers could arise. However, in my view this is not because the institutions themselves co-ordinated to claim the regulatory space. In the rule production process their role is better characterised as the interested observer rather than the coordinator of the process. Several considerations point in this direction. First, it is not clear that either at the end of the 1950s or the 1960s that intra-institution co-ordinating mechanisms were in place. ${ }^{72}$ Secondly, while it is correct that institutions expressed dissatisfaction at some pre-Takeover Code events, ${ }^{73}$ in relation to several others they were the beneficiaries of practices

\footnotetext{
69 For a more detailed account of how state expectation and the Bank of England resolved this investment banking compliance prisoners dilemma in the post-Notes period as well as a more detailed analysis of the substantive responses and how such responses connected to existing corporate law, and the interests of varying constituencies see KERSHAw, supra note 16.

70 Armour \& Skeel, supra note 47 at 1767-1772.

71 They view the Takeover Code as a 'good example' of 'the observed strategy [...] of coordinated lobbying for rules that were expected to maximise the joint welfare of institutional shareholders' $i d$. at 1771 .

${ }^{72}$ Welcome for a new initiative (20 July, 1967) THE TIMES observing that 'It might be a useful long stop if the insurance companies, investments trusts, pension funds and unit trusts all formed a protection committee to look after those interests which they have in common. Such body would have a formidable influence'.

73 For example, Edwin Herbert of The Industrial and General Trust, and later a representative on the Notes Working Group, observed in the wake of British Aluminium that 'where a change of control of a
} 
- at the expense of retail investors - that appeared to be in breach of the Notes. ${ }^{74}$ Although, as is the case with merchant bankers, one could make a case that regulation was in the long term interests of institutions even if they were tempted to take the low hanging value fruit associated with preferential non-compliance. Thirdly, and most importantly, it seems clear from the historical record that merchant banks controlled the drafting of both the Notes and the Code ${ }^{75}$ through the Issuing Houses Association, producing a Code that responded to the high profile takeover events that led to the Code whilst bonding takeover process to a financial advisory role. ${ }^{76}$ It is submitted that the more significant contribution of the institutionalisation of share ownership to takeover regulation in the UK was then an indirect one: its demand side contribution to the diffusion of share ownership created the conditions for the proliferation of hostile activity which, as observed above, altered the business model for investment bankers and generated strong incentives for them to take control of the regulatory process when action was co-ordinated by the Bank of England.

\section{ENFORCEMENT}

In the UK, unanimous constituency sign-up for the project was not only necessary for the project's momentum, it was central to its mode of enforcement. During the lifetime of the Code the Takeover Panel has acquired several state enforcement supports through the capital markets regulator prior to 2005 and after 2005 when the Takeover Panel became a state supervisory authority, through the courts. ${ }^{77}$ But it has never, and is unlikely ever, to use them. It continues to rely on the enforcement tools introduced at its inception which involves neither injunctions nor fines but the corporate law equivalent of the naughty step and being sent to your bedroom.

There are three tiers of Panel sanction that ensure compliance with the Code and the Panel's instructions. Such instructions could include a direction to comply with the Code or, much more rarely, to compensate parties who are injured as a result of non-compliance. The sanction regime provides for a pyramid of increasingly onerous sanctions which fall clearly within the responsive regulation umbrella: ${ }^{78}$ failing to comply with the Code could result in a private censure, a

\footnotetext{
company is envisaged, or where the nature of the company's business is to be changed, shareholders should first be consulted' - Watney Sears Silence (12 June, 1959) FinANCIAL Times.

74 Several bids that contributed to the view that regulatory action was necessary gave institutional investors preferential price treatment. See, for example: RTB wins control of Whiteheads (2 February, 1963) FinANCIAL Times noting that "the dealings in Whitehead shares aroused criticism in the Stock Exchange because different treatment was being accorded to different sellers"; Behind the scenes of the Wilkinson e Riddell Battle (29 June 1967) FinANCIAL Times; Aberdare wins MI battle: Call for Inquiry (13 July, 1967) FinANCIAL TIMES.

75 See The men behind the Code (27 March, 1968) FinanCial Times.

76 See II.B.4 below detailing this bonding.

77 Sections 952-956 Companies Act 2006

78 See BALDWIN ET AL, supra note 2.
} 
public censure or a 'cold shoulder'. The censures are really precursors / warning signs for cold shouldering and involve either a private or public dressing down. If parties continue to offend or the first offence is an egregious one then the Panel may issue a cold shoulder statement. The effect of a cold-shoulder statement is to inform all market participants that they cannot work with this person for the specified period of time in relation to a UK takeover. In the early years following the Panel's formation, all the trade associations, together with the Board of Trade in relation to licensed dealers, agreed that any of their members who dealt with such a cold shouldered person would be subject to trade association sanctions which could result, in theory, in an effective loss of licence for many of these participants. Today, the cold shoulder statement benefits directly from state support through the Financial Conduct Authority's Market Conduct Rules that provide that any person authorised to provide financial services business by the FCA must cease to work with the specified person in relation to takeovers and if they fail to do so may be sanctioned by the FCA, which again risks loss of licence. ${ }^{79}$ However, given the widespread compliance with the Code prior to this state support, it appears that the sanction worked effectively without it.

It is noteworthy that although this enforcement approach is widely considered to be highly effective, there are few public examples of sanctions being deployed. Although public censures do occur they are relatively rare. There has only been one in the past five years. ${ }^{80}$ And cold shouldering orders are extremely rare. In the history of the Panel there have only been two. The last one was issued in $2010,{ }^{81}$ but this was the first one for almost twenty years. ${ }^{82}$ It is common, and sensible, in corporate governance scholarship to draw conclusions about the probability of enforcement from evidence about the number of enforcement actions brought against market participants. Through the lens of the regularity of enforcement action by the Panel one might conclude that the probability of Code enforcement is low. This would be a serious error of judgment for any market participant. However, it is only a mistake that an outsider would make. The Panel signals a high probability of enforcement for breach through its close engagement with the bid. For every deal the Panel appoints a case officer who is, purportedly, available in real time 24/7. This provides an unrivalled level of interaction with, and oversight and control of, each deal..$^{83}$ The Panel's approach is not unfairly characterised as a surveillance culture with deal participants aware of the Panel's presence and oversight throughout the deal.

\footnotetext{
${ }^{79}$ FCA Handbook, Market Conduct Rule 4.

${ }^{80}$ For a more detailed analysis of the number of public censures see KeRSHAw, supra note 15 , chapter 4.

${ }^{81}$ Hearing Committee Decision in the case of Principal Capital Investment Trust Plc, [164]. The order was made for a three year period.

82 The first cold shoulder was made in 1992 and arose in relation to purchases of shares in Dundee Football Club Plc. This cold-shoulder order was made for an unlimited duration.

${ }^{83}$ For empirical detail on the number of companies with whom the Panel engages each year see John Armour et al, Private Enforcement of Corporate Law: An Empirical Comparison of the United Kingdom and the United States 6 JourNal OF EMPIRICAL Legal STUdies 687, at 717-718 (2009).
} 
Empirical evidence to support this account of such a surveillance culture is not available. However a recent case provides some more-than-anecdotal support for the this position. Re Expro International Group Pl 84 involved an idiosyncratic UK deal structure known as a scheme of arrangement. ${ }^{85} \mathrm{~A}$ scheme is a court controlled deal structure that can be used to effect a merger or the functional equivalent of a tender offer. ${ }^{86}$ To affect a scheme the parties must obtain the required approvals from shareholders but also court approval that the scheme is fair and reasonable. This case involved a deal between Expro and a bidder called Umbrellastream. The parties agreed terms and obtained the scheme approvals. However, at the same time there was what UK M\&A lawyers would call a virtual bid. In the shadows, Halliburton was lurking indicating that it might make an offer but never quite doing so. In such circumstances, the UK Takeover Code provides for a 'put-upor-shut-up' rule that requires such virtual bidders to either a make a bid (put-up) or announce that it will not make one (shut-up). ${ }^{87}$ If the bidder elects not to make a bid it cannot make an offer for the company in the following six months. ${ }^{88}$ However, when a bidder elects to 'shut-up' it can condition its election on certain events which if they occur will allow it to re-enter the fray. ${ }^{89}$ In this case Halliburton elected to 'shut-up' subject to the condition that if the court did not approve of the Umbrellastream scheme then it would be able to make a bid. The possibility of a bidding war for the target incentivised several hedge funds to oppose the application for the court's approval of the scheme. Halliburton instructed counsel to attend the scheme hearing. More interestingly, for our purposes, so did the Takeover Panel. What the Panel was doing at the hearing is at first blush rather unclear. Although the Takeover Code applies to schemes of arrangement, it had no role in the court's determination of whether or not to approve the scheme. The Code was not relevant to the outcome of the scheme. Nor was there any no scope for the court to opine on Code rules; and its judgment would not affect the application of the Code to the scheme. What then was the Panel doing instructing expensive counsel to attend the meeting? It was there to make Halliburton aware that it was there. To ensure that Halliburton did not say anything at all that could be in breach of its shut-up election. Any indication of a particular price or encouragement to create space for a bid would have been, in the Panel's view, a breach of the Code. The Panel's presence was designed to ensure that Halliburton was aware of this.

The nature of this command and control compliance culture is difficult to describe and, as noted, it has not been empirically documented. The above

\footnotetext{
84 [2010] 2 BCLC 514.

85 Part 26 Companies Act 2006.

86 A reduction and cancellation scheme involves the cancellation of existing shares in exchange for the deal consideration and then an issue of new shares to the bidder. See, Jenny Payne, SCHEMES OF ARRANGEMENT: THEORY, STRUCTURE AND OPERATION (2014).

87 Rule 2.6 Takeover Code.

88 Rule 2.8, Takeover Code.

${ }^{89}$ Note 2 to Rule 2.8 Takeover Code.
} 
example merely provides a flavour of it. Moreover, how the culture came into being is also undocumented and illusive. It clearly cannot be accounted for by the mere existence of a powerful self-regulatory enforcement tool that has rarely been used. For a body attempting to replicate the Panel's success, such self-regulatory enforcement arrangements would, and should, appear hopelessly utopian. The Brazilian self-regulatory takeover code does not attempt any such replication. Indeed it falls far short in this regard with no enforcement mechanism of any note. ${ }^{90}$ Yet in close attention to the Panel's success there is a key replication lesson, although not one that will necessarily be available in the Brazilian context. The lesson is that a significant compliance dividend can be obtained, and a culture of self-regulatory compliance generated, if key (and co-ordinating) market actors can be given a financial stake in the rules and their enforcement. Put differently, and discussed in detail below, the key to self-regulatory enforcement success is to, through the rules and process, bribe the quarter-back.

\section{Bribing the Quarterback: Creating Significant Financial STAKES IN COMPLIANCE}

For lawyers who encounter the Takeover Code in action for the first time it often involves a sense of surprise, if not disappointment. The reason for this is that the lawyers are not firmly in charge of what is a very law-like and detailed rules-based ${ }^{91}$ document. As the Code makes clear, it is the company's financial advisors that bear 'a particular responsibility' for ensuring that their clients comply with the Code. ${ }^{22}$ As a consequence of this, it is financial advisers (as well as lawyers) that perform a legal function for their clients. In meetings to discuss deal structure and compliance with the Code clients often turn to their bankers to understand how the Code works and to understand the Panel's likely response to any requests that are made. Of course, given the central role that bankers played in the drafting of the Code and the creation of the Panel this is unsurprising.

Accordingly, UK investment bankers have valuable human capital wrapped up in their ability to interpret the Code and to predict Panel judgments. Such individual and firm investments are enhanced by the secondee case officer system that the Panel deploys. According to this system, the Panel staffs itself, in addition to its limited full time staff, with secondees from financial advisors (including investment banks and financial consulting firms) and other members of the City establishment (including lawyers). In addition, at several junctures in the Code the role of financial adviser is hardwired into the takeover process. For example, a bidder cannot announce his intention to make a firm offer that will include a cash component without a 'cash confirmation statement' from the financial adviser

\footnotetext{
${ }^{90}$ The CAF Code provides for private censure, public censure and then 'withdrawal of the Panel seal', i.e., no longer being part of the CAF system (after a one year exit period) - Article 136 CAF Code.

91 Although the Code purports to be a form of principles based regulations, in addition to six General Principles, there are 300 pages of rules and sub-rules.

92 Introduction, 3(f) Takeover Code.
} 
confirming that the cash resources needed to close the deal are available to the bidder. ${ }^{93}$ Other, of the many, examples in which the Code builds in a role for the financial advisor include: the determination of whether or not to make a 'possible offer announcement'; $; 4$ the requirement for certifications from financial advisors in relation to profit forecasts; 95 and target management post-bid remuneration. ${ }^{96}$ As each of these roles and functions generates fee income, the Code becomes a source of revenue.

As compliance with the Code is very clearly in the significant financial interests of financial advisors it becomes in the financial interests of the brokers, accountants, the lawyers who they instruct and the companies, private equity houses, hedge funds who rely on their services. The lesson for effective enforcement of self-regulation from the Takeover Code is not only the hands-on involvement of the Panel and the innovative informal sanction of the cold shoulder mechanism, but also a more straightforward incentive story: selfregulation will work if you make sure that strict compliance is in the financial interests of the most important player in the marketplace.

By providing one market player with such a key role in the regulatory space we might have legitimate public choice concerns that the rules will quickly become skewed toward the interests of the advisors and of their clients. A strong case can be made that multiple specific examples of such bias, referred to above, can be found as well as a case that the exponential proliferation in the rule book is connected to financial advisor interests as it increases the scope for advice on Code interpretation and thereby solidifying a central role in the takeover process for bankers. However, with regard to the core of the Code that regulates bidder and target behaviour it seems unlikely that any particular interests would be more forcefully transmitted to the Panel than others. Advisors typically work with bidders and targets and, therefore, see the advantages and disadvantages of the rules from both sides on a regular basis. The investment bank is therefore unlikely to become an effective conduit for the interests of a particular constituency in any regulatory reform or enforcement process. Of course, if advisors specialise in working for particular repeat player clients such as private equity firms then their views may become weighted towards their client's regulatory preferences. But from the Panel's perspective for every advisor putting forward a pro-bidder view there is an advisor putting forward the target's perspective. Accordingly, this problem is of limited concern.

This is different of course than saying that the Takeover Code provides a neutral system of rules as between shareholders and managers. It does not. It

\footnotetext{
${ }^{93}$ Rule 2.7 Takeover Code.

94 Practice Statement No 20: Rule 2 - Secrecy, possible offer announcement and pre-announcement responsibilities (2008) refers to the 'particular responsibility of financial advisors for ensuring compliance with Rule 2' and that the financial advisors should be in control of drafting the announcement.

${ }^{95}$ Rule 28 Takeover Code.

${ }^{96}$ Rule 16.2 Takeover Code.
} 
clearly provides a pro-shareholder rule book. But this rule book is not the product of shareholder control over or bias in the rule making process, rather the product of the deeper shareholder rights bias in British business culture and company law. A bias that generated the different strands of public and political outrage from the takeover events in the 1960s, relating to both shareholder sovereignty and equality of treatment, to which the banker drafters of the Code directly responded. ${ }^{97}$

\section{Demarcating the Regulatory Space}

To operate effectively and ensure compliance with its rules, a self-regulator must 'own' the regulatory space within which it operates. If it does not do so market participants may attempt to subvert its rules by attempting to leverage the role of other lawmakers that may lay claim to the regulatory space. A self-regulator therefore requires either a regulatory space in which there is no other regulator or deference from such regulator. As detailed above, the Takeover Panel when it came into being benefited from both. ${ }^{98}$ The Takeover Code also teaches us that the ability of an effective self-regulator to control the regulatory space is not only a function of the absence or deference of other regulators and adjudicators, but also a function of certain 'keystone' rules that carve out that regulatory space. In the case of the Takeover Code there are two such rules: the non-frustration rule and the mandatory bid rule. The non-frustration rule is a rule that provides that where a bid has commenced or is imminent, target management cannot take any action that could prevent the shareholders from deciding on the merits of the bid without shareholder approval. This applies regardless of whether or not the board has any defensive motivation vis-à-vis the intended corporate action. As I have argued elsewhere ${ }^{99}$ the actual substantive effect of the non-frustration rule is overstated as the existing UK corporate law requires similar, although not identical, protection through the proper purpose doctrine. ${ }^{100}$ However, the nonfrustration rule's limited substantive impact should not be mistaken for its lack of importance to the Takeover Panel. In its absence, the question of the availability of defences and the effects they could have on bid timing and process would not

\footnotetext{
97 See note 24, 25 and 26. Elaborating this claim see further KERSHAW, supra note 15, Chapter 3.

98 Note also that when actions were brought in the courts for judicial review of Panel decisions the courts adopted an explicit and extremely deferential stance. They made it clear that although that they had the power to intervene - because the Panel, although a self-regulatory body, was performing state functions it would only be in the most egregious of circumstances in which they would intervene. Furthermore, the courts clarified that in the very rare event where they deemed intervention to be necessary, if the matter related to an ongoing takeover the court's ruling would be historic and not contemporaneous. This meant the court's ruling would only apply to future action by the Panel and would not alter the Panel's decision in the immediate case - R. $v$ Panel on Takeovers and Mergers ex p Datafin Plc [1987] QB 815 and R $v$ Panel on Takeovers and Mergers, exp Guinness plc [1989] 1 ALL ER 509.

99 David Kershaw, The Illusion of Importance: Reconsidering the UK's Takeover Defence Probibition 56 INTERNATIONAL AND COMPARATIVE LAW QUARTERLY 267-308 (2007).

100 The proper purpose doctrine now set forth in section 171(b) of the Companies Act 2006 as the duty to use powers for proper purposes prohibits (without ex-ante or ex-post shareholder approval) the use of corporate power to interfere with the fundamental shareholder rights to vote and to decide on whether to accept or reject a takeover offer.
} 
be in the hands of the Takeover Panel but in the hands of the courts interpreting the scope of application of the proper purpose doctrine. The Takeover Panel would often be forced to play second fiddle to the courts undermining both its autonomy and the perception that it controls the rules of the game in the UK takeover market.

The second 'keystone rule' is the mandatory bid rule. There is of course no such thing as a mandatory bid. All mandatory bids under the Takeover Code are voluntary bids because the bidder decides voluntarily to cross the mandatory bid threshold. It might do so to enhance its ownership position in the target prior to the offer if the bidder expects resistance from the target. The rules that apply to mandatory bids are more onerous than those that apply to voluntary bids. For example, the pricing look-back period for a mandatory bid is twelve months and rather than three months ${ }^{101}$ and there is virtually no scope for any conditionality beyond a simple majority acceptance threshold. ${ }^{102}$ Accordingly, most bidders elect for voluntary bids. However, without the mandatory bid rule the Panel would not be able to maintain its stringent regulation of voluntary bids as the costs of the incremental acquisition of control of the target over time would in many cases be lower than a Code controlled voluntary bid. This would force the Panel to reduce the costs of voluntary bids by relaxing many of the rules.

Although both of these rules are contentious, there are many valid arguments in their favour. ${ }^{103}$ However, aside for the arguments for and against the rules, it is interesting to observe that the centrality of these rules to the creation and operation of self-regulation of the market for corporate control gives the regulator a distinct vested interest in these rules that may not be aligned with the interests of the companies it regulates or the economy in which those companies operate. Accordingly, in relation to such keystone rules the technique of self-regulation may bias substantive outcomes in an unexpected way, independently of the rule bias sought by constituency interests. It follows that where events problematise such rules we cannot rely on the self-regulator - even one that is truly independent of constituency interests - to be a neutral arbiter of the suitability and efficiency of such keystone rules.

Recent events in the UK lend support to this view. The high-profile, initially hostile, takeover of Cadbury Plc by the US corporation Kraft Inc raised the question in political, business and media circles as to whether UK companies were too exposed to hostile deals and two easily taken over. At a speech at the SAID Business School the outgoing Chairman of Cadbury, Roger Carr, asked whether the prevailing takeover rules 'were fair and helpful to the long term success of Britain's future'.104 In this speech, as possible reform responses $\mathrm{Mr}$ Carr

\footnotetext{
${ }^{101}$ Rule 9 Takeover Code.

102 Rule 9 Takeover Code.

103 See Edmund Schuster, The Mandatory Bid Rule: Efficient, After All (2013) 76 Modern Law Review 529-563; KERSHAW, supra note 15, Chapter 1.

${ }^{104}$ Speech available: http://podcasts.ox.ac.uk/roger-carr-cadbury-hostile-bids-and-takeovers.
} 
considered both the disenfranchisement of short term shareholders in hostile bid contexts and an increase in the minimum acceptance condition from a simple to a super majority. We cannot explore the merits of these proposals here, but what should be noted is that both ideas explored ways in which boards could be directly or indirectly empowered and supported over the long term. An alternative means of altering the balance of power would be to provide boards with greater defensive capability which inter alia would involve reform to the non-frustration rule. Following Carr's comments, political and media attention on the role the Code's rules was heightened and the Takeover Panel responded with a consultation process and rule changes that, at the margin, may have dampened takeover activity. ${ }^{105}$ For our purposes, what matters here is not whether Carr was right or wrong, that matters is that there was no serious engagement in the consultation process regarding the merits of the non-frustration rule; 106 and no attempt to gather empirical evidence on the effects that this rule may have UK companies and the UK economy. This key issue was not placed in play at all and the debate was ultimately channelled into marginal, if useful, reforms. The keystone rule remained untouched.

\section{MARKET CONTROLLED REGULATION: COMPLY OR EXPLAIN}

One of the most important governance phenomena of the past 20 years has been the introduction of market controlled corporate governance codes designed to guide companies towards best practice in the composition and structure of the boards. These codes invariably address the number of non-executive directors and their role and independence of management; and board committee structure and the staffing of these committees. They may also cover separation of the roles of Chairman and Chief Executive Officer; remuneration guidance; and internal controls. These Codes are typically - although as the US experience shows not always ${ }^{107}$ - 'comply or explain' codes. 'Comply or explain' means that companies are required to comply with the recommendations set forth within the code or to explain to their shareholders why they do not comply. The underlying idea of such codes is to set forth guidance on governance best practice that one would expect

\footnotetext{
105 Including a tightening up of the put-up or shut rule to commence automatically from the first announcement (Rule 2.6 Takeover Code) and the prohibition of deal protections (Rule 21.2 Takeover Code). See Consultation Paper Issued By the Code Committee of the Panel: Review of Certain Aspects of the Regulation of Takeover Bids (PCP 2010/2).

106 As I have argued elsewhere, a strong case can be made that in fact the non-frustration rule does not make a significant difference to exposure levels for UK targets (see Kershaw, supra note 99) however, before one could consider altering UK company law to make it more board friendly the non-frustration rule would have to be addressed.

107 Although some composition rules are set forth in the Securities Exchange Act of 1934, as amended by the Sarbanes-Oxley Act, most composition and structure rules are set forth in the governance rules of the trading platform, for example, in Section 3.03A of the NYSE Listing Manual.
} 
most companies to follow but to leave companies the freedom to adapt governance rules and structures to their own conditions and circumstances: one size does not fit all therefore one size is not imposed on all. However, departures from the code must be justified to shareholders who can assess and respond to the non-compliance explanation either through voice or exit.

In most instances it is difficult to describe these comply or explain codes as the products of self-regulation. Although the code rules are typically produced by representatives of market actors who are the members of the code committee or commission who produce the rules, such commissions invariably have been formed by or are connected to the State, members are often appointed by the state or the state at least has a say in the broader membership, and typically the obligation to comply or explain is set forth in mandatory law. These codes then are archetypal examples of market controlled regulation whereby the state seeks to achieve its regulatory objective by co-opting the market actors to form and tailor the rules. In doing so it takes the risk that control of the rules may bias the rules in favour of market actors, in order to obtain the substantive benefits of informed and tailed business regulation and the compliance and norm formation benefits that may flow from market ownership of the regulatory space.

\section{FOUNDATIONS}

The first comply and explain corporate governance code was the UK's Code of Best Practice issued in 1992, which formed the basis of what today is known as the UK Corporate Governance Code. The first iteration of this Code resulted from Sir Adrian Cadbury's investigation into the 'Financial Aspects of Corporate Governance'. The 'Cadbury Committee' was - like the Takeover Code and Panel the product of a the combination of a deferential conception of the British State, pressure generated by public outrage in relation to several corporate and accounting scandals, ${ }^{108}$ and the co-ordination and forced entry of market participants into the 'contracting zone' by the London Stock Exchange and the quasi-state body, the Financial Reporting Council, who commissioned the Report. ${ }^{109}$ The Financial Reporting Council (the FRC) itself was then a recently formed response to the failed self-regulation of accounting standards. ${ }^{110}$ After the Cadbury Committee's recommendations were delivered, the FRC became responsible for the maintenance and revision of the Code. The FRC is a quasi state-body with certain formally designated state functions ${ }^{111}$ and its Chairman and CEO are appointed by the Secretary of State for Business. Nevertheless, this is a body controlled by market constituents, with a majority of FRC appointed board

\footnotetext{
108 See for example, $M r$ Maxwell's costly legacy (5 December 1991) FINANCIAL TimES.

109 'DTI will back in-depth review of Companies' (May 31 1991) FINANCIAL TimES

110 Sir Ron's tough package sets standard (10 November 1988) FinANCIAL TIMES.

111 Part 42 Companies Act 2006.
} 
members from the business and accounting worlds and with no delegated representatives from other regulators or government. ${ }^{112}$

From its inception the Code has been a 'comply or explain' Code. However, for companies subject to the Code the requirement either to comply or explain is mandatory. Pursuant to the FCA's listing rules, premium listed companies ${ }^{113}$ must either must provide a statement in their annual reports setting forth whether they comply with the Code's provisions or explaining their failure to comply. ${ }^{114}$ The Code itself recommends that explanations provide background to, the rational for and risks associated with the departure for the Code. ${ }^{115}$ However, there are no clear guidelines in the FCA's rules on the level of detail that must be provided in company's explanations of non-compliance. A statement providing that 'the provision is unsuitable for our company' would appear to suffice for the purposes of compliance with the explain obligation. It is noteworthy that in this regard the FRC has no sanctioning powers, and that to-date there has been no action by the FCA or its predecessor, the Financial Services Authority, in relation to companies failure either to explain or in relation to the quality and detail of the explanation.

Worldwide at the beginning of this century there was an exponential increase in the production of Corporate Governance Commissions and Codes following multiple high profile corporate and audit failures, particularly in the United States. ${ }^{116}$ Although the governance response in the United States generated mandatory rules imposed through exchanges and trading platforms, ${ }^{117}$ most other jurisdictions elected for the less intrusive comply or explain approach. In Germany, for example, a Corporate Governance Commission was appointed by the Federal Government in 2001 and a Code introduced in 2002.118 Publicly traded companies are required to either comply or explain non-compliance pursuant to section 161 of the German Stock Corporation Law. Although the German state provided for its formation, the Commission is staffed (by Government appointment) with shareholder and management representatives as well as auditors and academics. The Austrian and Dutch Corporate Governance Code adopt a similar approach of state authorised commissions and statutory

\footnotetext{
112 For current board membership see: https://www.frc.org.uk/About-the-FRC/FRC-structure/FRCBoard/Members.aspx.

113 Companies listed on the Main Market of the London Stock exchange may elect to have a premium or standard listing. Premium listed companies are subject to more onerous listing and governance requirements.

${ }_{114}^{11}$ Listing Rule 9.8.6(5).

115 UK Corporate Governance Code, [3].

116 Including, most notably, the failures of Enron, WorldCom and Tyco.

117 See, for example, Section 3.03A of the NYSE Listing Manual for corporations listed on the NYSE.

118 Note that the stimulus to create a Corporate Governance Code was pre-Enron with a Code generated by academics in 1999 and the Commission appointed prior to Enron's collapse in September 2000 - See Eddy Wymeersch, Corporate Governance Codes and their Implementation (http://papers.ssrn.com/sol3/papers.cfm?abstract id=931100).
} 
comply and explain obligations coupled with Commissions staffed by market participants. ${ }^{119}$

\section{ComplianCE LeVEls}

The typical expectation of students who encounter the 'comply or explain' idea for the first time is that compliance levels will be low. We tend to think of regulation, particularly regulation that represents a response to failings, as directing participants to take actions contrary to their preferences. It follows that if you give the regulated a choice about compliance then they will elect not to comply. This concern was acknowledged by the Cadbury Committee which warned market participants that if they did not take the recommendations seriously 'it is probable that legislation and external regulation will be sought to deal with some of the underlying problems'.120 Yet contrary to this expectation, compliance levels for comply and explain codes are high, and very high amongst large, publicly traded companies. In the UK, Arcot and Bruno ${ }^{121}$ report compliance levels of between $85 \%$ to $95 \%$ of companies in relation to a subset of key - arguably the most important - Code provisions. ${ }^{122}$ Arcot and Bruno did note, however, that where there was non-compliance, the relevant explanation was often very brief and uninformative. ${ }^{123}$ Over the course of the Code's lifespan Arcot and Bruno's results confirm that the UK Code is driving profound structural governance changes, even where those changes are contentious. Consider, for example, the recommendation to separate the roles of chairman and CEO, ${ }^{124}$ an issue which continues to divide opinion both within the UK and across jurisdictions. Between 1991-1993 Conyon documents an increase in separation rates from 48\%-64\%.125 Arcot and Bruno find that by 2003 the compliance rate had increased to $92 \%$. Another example of how the Code appears to be driving change is in relation to the length of senior management's service contracts. As of 2003 Arcot and Bruno find weak compliance levels in relation to the Code provision recommending maximum one year service contracts. Several years after their study, this is a provision in relation to which one would struggle today to find any companies that do not comply with this provision. In a later study, with a smaller sample but a broader assessment of compliance with all (at the time) 48 Code provisions, Seidl,

\footnotetext{
119 In Austria the comply or explain obligation was made mandatory pursuant to the Austrian Business Code Amendment Act 2008. Pursuant to the Netherlands Civil Code, Dutch companies must comply or explain non compliance with the Dutch Corporate Governance Code.

${ }^{120}$ Report of The Committee on the Financial Aspects of Corporate Governance (1992), [1.10].

121 Sridhar Arcot and Valentina Bruno, In Letter but not in Sprit: An Analysis of Corporate Governance Available at SSRN: $\underline{\text { http: } / / \text { ssrn.com/abstract }=819784}$.

122 They code 8 provisions: Chairman/CEO separation, appointment of a SID, number NEDS, \% of NEDs, service contract terms, nominations committee, remuneration committee and audit committee. 123 See id. $18-22$.

124 UK Corporate Governance Code, A2.

125 Martin Conyon \& Chris Mallin, A Review of Compliance with Cadbury 22 Journal of GeneraL MANAGEMENT 14 (1997).
} 
Sanderson and Roberts found that approximately 63\% of the top 80 companies (by market capitalization) were fully compliant with the Code whereas only $34 \%$ of the bottom companies were fully compliant. 126 The top 80 companies had an average of 0.96 deviations and the bottom 50 an average of 1.49 deviations.

If one turns to continental European comply or explain Codes compliance levels are high, although again the quality of explanations where there is noncompliance is considered to be poorly informative. ${ }^{127}$ The German Code makes a distinction between recommendation and suggestions. Compliance rates for DAX 30 companies in relation to recommendations are in the high 90s percentile and for suggestions in the high 80s. ${ }^{128}$ This represents a notable increase on 2006 when only $40 \%$ of DAX companies were fully compliant and only $10 \%$ of MDAX (midcap) companies were in full compliance with the Code. ${ }^{129}$ Dutch compliance rates are high 90s percentile for large caps although compliance rates drop for mid and small caps $\left(89 \%, 88 \%\right.$, respectively). ${ }^{130}$

Care needs to be taken, however, in assuming that the existence of a comply or explain governance code coupled with high rates of compliance necessarily represents a new and distinctive contribution to governance. Many corporate governance codes have extensive sections than merely replicate the existing legal position as set forth in the applicable Corporate Code. The Austrian Corporate Code, for example, explicitly acknowledges that the Code is based on Austrian corporate and securities law, as well as OECD Principles. ${ }^{131}$ The German Code contains many provisions that again merely replicate corporate law and practice. For example, the German Code contains provisions referring to the unavailability of multiple voting rights, which for most companies are unavailable under German law. ${ }^{132}$ Its section on the management board (Vorstand) involves in large part a replication of existing mandatory corporate law. ${ }^{133}$ Furthermore, many of the provisions in the Code would not be viewed by many corporate governance scholars as governance terms at all rather just good process guidelines. For example in Provisions 2.2.4 of the Code there is a suggestion that the general

\footnotetext{
126 David Seidl, Paul Sanderson \& John Roberts, Applying 'Comply or Explain': Conformance with Codes of Corporate Governance in the UK and Germany (http://www.cbr.cam.ac.uk/pdf/WP389.pdf).

127 This latter concern has led the European Commission to encourage companies to improve the quality of explanations. See European Commission Recommendation on the quality of corporate governance reporting $(2014 / 208 / \mathrm{EU})$

128 See Axel Weder and Jenny Bartz, Corporate Governance Report 2013: Abweichungskultur und Unabhaengigkeit im Lichte der Akzeptance und Anwendung des Aktuellen DCGK (available at: http://www.bccg.tu-berlin.de/main/publikationen.htm). See also: Paul Davies at al, CORPORATE BOARDS in EUROPEAN LAW: A COMPARATIVE ANALYSIS (2013).

129 See id.

${ }^{130}$ Rapport Monitoring Commission Corporate Governance Code (2012) at

http://www.commissiecorporategovernance.nl/rapport-2012.

${ }^{131}$ See Preamble, Austrian Corporate Governance Code. (http://www.wienerborse.at/corporate/pdf/CG\%20Codex\%202012 v5 englisch.pdf). .

132 Provision 2.1.2 German Corporate Governance Code (http://www.corporate-governancecode.de/eng/download/kodex 2013/D_CorGov final May 2013.pdf). Multiple voting rights are now generally prohibited for the stock corporation in the Stock Corporation Act, s 12(2), and voting caps for public companies in s 134(1).

133 See id. For example, section 4.
} 
meeting last for four to six hours. Provision 2.3.3 suggests that that the general meeting should be followed by modern communication. Of course, these Codes do take important steps to alter certain existing practices. Most importantly in relation to the German Code is the recommendation to limit the longstanding practice of management board members retiring to the supervisory board ${ }^{134}$ or the provision recommending that supervisory board members do not take more than three supervisory board directorships. ${ }^{135}$ The Code provides both a recommended limit on the number of supervisory board members who are former management board members and for a cooling off period for managers of two years before they are eligible for supervisory board membership. As of 2013, these provisions attracted between low $70 \mathrm{~s}$ and high $90 \mathrm{~s}$ percentile compliance, with larger companies more likely to comply. 136 The point here is not that these Codes do not, or do not have the potential to, make a governance difference, but that we must parse often lengthy codes for provisions that are different from applicable corporate law or are of real governance significance. This in turn means that we also need to be wary of overall compliance data which details partial compliance and percentage deviation from the all Code provisions. There is a risk with this data that identified partial compliance represents merely compliance with existing mandatory law or non-governance provisions. ${ }^{137}$

These caveats aside it remains clear that in relation to a substantial body of companies comply or explain governance codes alter the governance rules and practices of those companies even though there is no requirement to actually comply. In Germany, the UK and the Netherlands, for example, high 80s and 90s percentile of the largest publicly traded companies comply fully with the Codes. Indeed, in some jurisdictions, for example the UK, excessive compliance is viewed as the primary enforcement problem. The FRC has become concerned that companies do not take seriously enough the idea that they can explain noncompliance. Recent amendments to the Code attempt to foreground this option to companies. ${ }^{138}$ The UK's post-crisis Walker Review into the Governance of Banks and Financial Institutions lamented the fact that many of the UK Corporate Governance Code's rules may be inapt for banks yet banks did not opt out and explain non-compliance. ${ }^{139}$ Walker was particular concerned in this regard that the Code's focus on the independence of non-executive directors resulted in boards of banks staffed with directors who did not understand modern banking and

\footnotetext{
134 See id. 5.4

135 See id. 5.4 .5

136 See Weder \& Bartz supra note 128 at 890.

137 See, for example, Seidl supra note 126. See Weder \& Bartz supra note 128 separating out the existing mandatory law but not the non-governance like / business practice provisions from the overall compliance levels - but importantly providing provision level compliance information.

138 UK Corporate Governance Code, Comply or Explain, 4.

139 A Review of Corporate Governance in UK Banks and other Financial Industry Entities (2009) Observing at [2.16] that some shareholder 'appear to have interpreted [comply or explain] in a somewhat minatory way as "comply or else"'.
} 
financial services. ${ }^{140}$ Whether or not this was the case across all UK banks is debatable, ${ }^{141}$ but Walker was surely correct that UK banks did not consider that they had space to explain non-compliance. This has led some commentators (unsuccessfully) to propose changing the terminology to 'apply and explain'.. ${ }^{142}$ The idea being that companies need to distance themselves from a 'compliance culture' and that using 'apply' instead of 'comply' will enable this. ${ }^{143}$

\section{ENFORCEMENT DRIVERS}

These Codes make recommendations many of which are not in the senior managers' interests. Separation of Chairman and CEO in the UK and management board cooling off periods in Germany are good examples of such managerially unfriendly rules. Such rules are not enforced by regulators. There are no direct financial consequences of non-compliance. Yet the compliance levels are very high. What explains this? Where do we find the compliance pressures?

It seems clear that the compliance pressure arises through a combination of market/investor expectation about good governance as benchmarked by the applicable Code coupled with reputational capital concerns for managers but also, more importantly, for non-executive directors whose rents are a function of their ability to obtain other (parallel or subsequent) non-executive positions. This reputational capital is. inter alia, a function of directors' association with companies that are known for good and not bad governance practices. The potential reputational downside of non-compliance for directors is a function of the likelihood that investors (fund managers) will reject the explanation and put their head above the parapet to complain about non-compliance and 'bad governance'. The question of importance here is: what factors determine an investor's response to explained non-compliance?

Ideally, such a response is a function of the arguments about the benefits and downsides of the provision itself and the provision's application to the company in question. It may be the case that compliance levels are high because attempts to explain non-compliance have met with careful consideration by institutional investor and their fund managers but ultimately their rejection of the noncompliance and subsequent direct and indirect pressure to comply. However, there are several factors which may distort such an 'ideal' shareholder assessment of non-compliance. First, consider the costs associated with that analysis for the fund manager. Although the economic benefits for the investor of the company

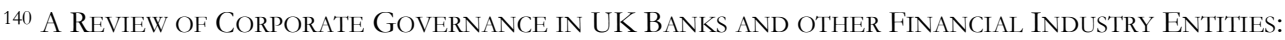
CONSUltation Document (2009) [3.08]-[3.12]

${ }^{141}$ Compare the Board of HBOS in 2006 (little to no knowledge of banking and financial services) with the board of the Royal Bank of Scotland (significant financial services experience). See HBOS Annual Report and Accounts 2006 (available at:

http://www.lloydsbankinggroup.com/globalassets/documents/investors/2006/2006 hbos ra.pdf at 90) with RBS's Annual Report and Accounts 2006 (available at: http://www.annualreportowl.com/RBS/2006/Annual\%20Report) at 101.

142 See Call for More Flexibility on Code (25 June, 2009) FinANCIAL Times.

${ }^{143}$ Note that the King Code of Governance for South Africa adopts an 'apply or explain' approach.
} 
complying or not complying with the provision are likely to be very uncertain, opaque and distant, the opportunity costs of the governance conversation are clear and immediate. It is cheaper in such circumstances to have a pro-compliance bias across all portfolio companies which resists detailed investigation, engagement and conversation and relies on the best practice recommendation of the expert market regulators. Of course, investors can rely on, and pay for, the advice of governance specialists, ${ }^{144}$ however, such specialists have a deep vested interest in a strong compliance culture that keeps governance relevant. This surely gives such advisors a pro-compliance bias. Second, many passive fund managers may themselves be subject to external pressure to be seen to be acting in order to be seen to be doing their job. Such pressure could come from the ultimate investors - e.g., pension trustees, but could also come from government. In the UK, for several decades the monitoring and activism of shareholders has been on the regulatory agenda. Government ministers who have decried the role of shareholders prior to the crisis describing them as 'absentee landlords'. ${ }^{145}$ Most recently this resulted in the introduction of a 'comply or explain' Stewardship Code for investors. ${ }^{146}$ Fund managers sensitive to these pressures and criticisms are aware that they need to be seen to be acting, even when they are of the opinion that it is not in their, or their ultimate investors', economic interests to invest resources in being more attentive and active. Opposing non-compliance with the Corporate Governance Code is arguably a very cheap way of being responsive to such external pressures. As Ed Rock and Marcel Kahan have recently taught us, ${ }^{147}$ in each jurisdiction we need to understand the symbolism of investor activism which may reveal that the reason for acting is very different than the reason given for acting. It seems likely in the UK that compliance pressure comes in part from the symbolic capital investors can earn by opposing - loudly - non-compliance, regardless of explanations. High profile examples of shareholder dissatisfaction with Code non-compliance would appear to fit with such an understanding. Consider, for example, the decision in 2008 by Marks \& Spencer Plc, a household name in British retail, not to comply with the Code provision recommending separation of the chairman and CEO roles. Investors treated the separation rule as a mandatory provision, accusing the company of being 'in breach' of the Code, leading one City commentator to observe that 'apparently the English word "or" in comply or explain has lost its meaning'. ${ }^{148}$ If this correctly describes investor motivation some of the time for objecting to non-compliance, then directors of companies cannot expect a fair hearing for their explanations. Furthermore, it seems probable that as soon as one

\footnotetext{
144 See generally, for example, Stephen Choi, Jill Fisch, and Marcel Kahan, The Power of Proxy Advisors: Myth or Realty (2010) 59 EMORY LAW JOURNAL 870.

145 Different kinds of company ownership are gaining in popularity (10 October, 2011) FINANCIAL Times.

146 UK STEWARDSHIP CODE available at: https://frc.org.uk/Our-Work/Codes-Standards/Corporategovernance.aspx.

147 Marcel Kahan, and Edward B Rock, Symbolic Corporate Governance Politics 94 B.U. LAw REv. 1997 (2014). 148 'Why M\&S Shareholders should think before we speak' FinANCIAL Times (8 April 2008).
} 
investor publicly complains, other investors will line up to drink at the trough of symbolic capital and directors will suffer reputational damage regardless of the strength of the justification for non-compliance. The larger and more high profile the company the more likely it will trigger a knee jerk 'object and shout loudly' response from the investment community. And the more likely that directors will comply rather than bother to explain why non-compliance makes sense, even when it does.

\section{The Effects of Regulatory Technique on Rule Choice}

As noted in the Introduction to this chapter, one of the concerns about delegating regulatory authority to the market place is that the regulation will have a promarket bias. Is it then surprising that the UK's market-controlled comply or explain Code is much more detailed and demanding, and much more proshareholder than mandatory governance regimes subject to state regulatory oversight such as those found in the United States? ${ }^{149}$ Two familiar explanations offer themselves for this variation, but neither are satisfactory. First, that the market-controlled rule-making process has been captured by the interests of institutional shareholders which have pushed the Code's shareholder orientation. Indeed, it is clearly the case that for the past-two decades institutional investors themselves and through their trade associations have exerted a strong public governance voice in the UK. However, a case for the overweighting of such direct influence is difficult to make when one considers the background of the key players of the members of the Cadbury Committee, the membership of the FRC or the leading players in governance reform such as Sir Adrian Cadbury and Sir Derek Higgs. ${ }^{150}$ Second, that the Code's shareholder primacy bias may be an extension of, or a reflection of, UK company law's and legal culture's established shareholder rights orientation. ${ }^{151}$ Whilst a pro-shareholder legal environment is surely an important contextual factor, given the absence of these type of rules until the 1990s it is clearly only an ancillary driver.

The primary driver of this rule detail and rule orientation, it is submitted, is the effect of the comply or explain technique itself on the market-controlled regulator's outlook. The market-controlled regulatory bodies charged with drafting and amending a comply or explain code will approach their task very differently than a body tasked with drafting a set of mandatory governance rules. The latter is aware that the rules it selects must be adopted by the subject companies. It is, therefore, likely to be highly attuned to the authority/accountability ${ }^{152}$ trade-offs associated with different rule choices and much more wary of changing the rules in the face of governance scandals. In contrast, a 'comply or explain' regulator may

\footnotetext{
149 S.19(b)(1) Securities Exchange Act of 1934 requiring SEC approval of self-regulatory organisation rule changes following a SEC controlled consultation process.

150 Both of whom played major roles in UK companies.

151 See generally, David Kershaw, Company Law in Context: TeXt and Materials (2nd eds, 2012).

152 K. Arrow, 'The Limits of Organization' (1974) Fels Lecutures on Public Policy Analysis 77.
} 
feel that she has more room to ignore, or at least be less concerned about, the trade-offs and to 'aim high' by providing truly best practice rules. This is because in such a regulator's minds-eye the trade-off, if it needs to be made, can be made by the company itself. That is, built into the comply or explain approach is the safety value that if the regulator gets it wrong for the company in question the company may simply ignore the rule and explain why. Such an outlook would also make a 'comply or explain' regulator more receptive to calls for reviews of, and changes to, the rules in the face of public and political pressure to address governance scandals. Where comply or explain works as it is designed to such responsiveness to accountability pressures and a best practice outlook are not problematic. However, if comply or explain malfunctions for the reasons discussed above and in effect turns an optional regime into a mandatory regime then when combined with such a regulatory outlook there is a strong case that comply or explain is a sub-optimal regulatory technique that is likely to result in a regulatory overweighting of accountability concerns.

Take, for example, governance rules that determine whether a director is independent or not. Very demanding independence rules that provide for nobusiness relations with the company or long employee cooling-off periods will exclude many individuals with the right skills and knowledge to perform the directorial role effectively: to exercise the managerial function and to bring industry relevant experience, contacts and networks to bear. There is a trade-off between tight independence rules and the pool of knowledgeable directors: the tighter the rules, the shallower the available pool of directors. A trade-off that has been brought to light by the financial crisis. A comply or explain regulator may be more likely to select demanding rules that take independence seriously because she knows that if the rules are not suitable the company can elect not to comply with the independent non-executive recommendation and to appoint a nonindependent but knowledgeable director. In an optional comply or explain environment there is, in theory, no demarcated pool of talent because companies can dip into the non-independent pool. In contrast, in a mandatory rule environment, as is the case for example with corporations listed on the New York Stock Exchange, ${ }^{153}$ there is no option not to comply with the $50 \%$ independent non-executive director requirement and appoint the non-independent knowledgeable director. In such a mandatory environment the regulator will be acutely aware of the need to ensure that the definition of independence does not cut off the supply to the talent pool. However, if in a comply or explain environment companies experience the rules as mandatory rules then companies are faced with the same predicament as companies in the mandatory regime but with a regulator who thinks that the regime's non-compliance flexibility gives it more room to set rules that represent ideal standards. Of course a regulator could adjust its approach to rule-making to take account of an over-compliance culture.

${ }^{153}$ NYSE Listing Manual, 303A.01 and A.02. 
However, such over-compliance with a rule may equally be viewed by the regulator as the broad affirmation of its rule-making choices. When faced with interpretations of empirical facts that challenge or affirm our identities and roles, invariable people select the interpretation which defensively affirms their identity and their prior actions. ${ }^{154}$ It is, therefore, improbable that one would see such an adjustment by a 'comply or explain' regulator to its rule-making outlook.

It is problematic to attribute jurisdictional variation to any particular driver. There are likely to be many drivers of variation. It is submitted however that a comparison of the UK corporate Governance Code with the US rules as set forth, for example, in the NYSE Listing Rules, raises concerns that the above suboptimality problem is present in the UK. Both jurisdictions have a $50 \%$ independent non-executive director requirement. ${ }^{155}$ However, the independence definition is much more demanding in the UK than in the US. The UK has, for example, a cooling off period of five rather than three years under the NYSE rules. ${ }^{156}$ In the UK any performance based pay for independent directors renders them presumptively non-independent, ${ }^{157}$ as does nine years continuous service; the NYSE rules contain no such limitations. ${ }^{158}$ It is of course empirically very difficult / impossible to assess whether such rules are resulting in the staffing of UK boards with independent but unknowledgeable directors. The consequences of this being the case are reason enough to consider whether the UK should step back from governance leadership. It may also be a salient lesson that there is always a darker side to every governance innovation and that in practice we may find that regulatory theory - such as the probable bias associated with the delegating regulatory power to the regulated - may be significantly wide of the mark.

\section{Cultural governanCE Beyond the TICKED-BOX}

A traditional view of self-regulation focuses on the creation of law-like rules produced by market actors. More contemporary ideas of how to get the market to self-regulate focus less on enabling market actors to create and enforce rules applicable to all market actors, and more on facilitating pro-regulation norm formation within the players themselves: within the cultures of the firms and within the heads and identities of their managers and employees. If successful, this is true self-regulation in the literal meaning of the term and external rules, whether state- or market-controlled, become far less important as internal firm norms ensure targeted behaviours. This approach to regulation has multiple

\footnotetext{
${ }^{154}$ See generally, C.M. Steele, 'The psychology of self-affirmation: sustaining the integrity of the self' IN L BERKOWITZ (EDS) ADVANCES IN EXPERIMENTAL SOCLAL PSYCHOLOGY (1988) 261; G.L. Cohen and D.K. Sherman, The Psychology of Change: Self-Affirmation and Social Psychological Intervention' (2014) 65 ANNUAL REVIEW OF PSYCHOLOGY 333.

155 NYSE Listing Manual, 303A.01; UK Corporate Governance Code, B.1.2.

156 UK Corporate Governance Code, B.1.1; NYSE Listing Manual, 303A.02(b)(i).

157 UK Corporate Governance Code, B.1.1.

158 UK Corporate Governance Code, B.1.1.
} 
academic labels, including meta-regulation, ${ }^{159}$ principles-based regulation ${ }^{160}$ and process-based regulation. ${ }^{161}$ The idea is that the regulator sets forth broad objectives and then requires the regulated firms to explore processes and procedures to enable those goals to be realised. ${ }^{162}$ This both utilises local knowledge to provide tailored firm-level regulation but also creates conversations and processes that bias local norm formation. ${ }^{163}$ Several factors contribute to the likely success of this regulatory strategy that we cannot explore in detail here. First, and most importantly, clear and credible buy-in by senior management and the board which drives internal (firm-level) enforcement of failures to engage with the processes. ${ }^{164}$ Secondly, the subject firms' incentives, in particular, but not only, those of senior management, must not be demonstrably non-aligned with the regulatory objectives. ${ }^{165}$

While increasingly this strategy is being used in the regulation of corporate activity, it has not featured significantly in corporate law. One area where it is deployed in is in relation to board performance. Again we see the UK as market leader in the use of this innovation. Whether this is connected to a traditional deference to market-solutions which remains embedded in the UK's regulatory psyche is clearly plausible, although speculative. The FRC has become increasingly aware that ticking several board composition and structure boxes provided by comply or explain codes may not necessarily drive improved performance in the board room. In this regard a key, if innocuous, change in the UK Corporate Governance Code in 2010 provided that boards must undertake a 'formal and rigorous' annual evaluation of their performance. As per the process-based regulation tool-kit, the FRC also provides a non-binding set of objectives and guidance on both board effectiveness and the effectiveness of the different directors including the $\mathrm{CEO}$ and $\mathrm{CFO}$, the chairman of the board, the lead independent non-executive director (known as a senior independent director) and more

\footnotetext{
159 Christine Parker, Meta-Regulation: Legal Accountability for Corporate Social Responsibility, in THE NEW Corporate Accountability: Corporate Social Responsibility and the Law. 33 (D. McBarnet ET AL., EDS., 2007).

160 Julia Black, Forms and Paradoxes of Principles-Based Regulation, 3 CAPITAl Markets L. J. 425 (2008) (identifying cultural change as one of the potential advantages of this type of regulation,which she labels principles-based regulation).

${ }^{161}$ Dan Awrey, William Blair and David Kershaw, Between Law and Markets: Is there a Role for Culture and Ethics in Financial Regulation 38 DeLAWARE JOURNAL OF CORPORATE LAW 191 (2013).

162 See for example, the UK Financial Services Authority's 'Treating Customers Fairly' initiative: See FSA, Treating Customers Fairly, http://www.fsa.gov.uk/doing/regulated/tcf.

163 This view finds support in both organisational and sociological theory. See, e.g., Susan Silbey et al., 'The Sociological Citizen' Relational Independence in Law and Organizations, 59 L'ANNEE SOCIOLOGIQUE 201, 218 (2009) (describing a case study in which project engagement resulted in a "perceptual and moral transformation"); see also Clifford Geertz, "Thick Description: Toward and Interpretative Theory of Culture', in Interpretation of Cultures: SELECTED Essays 3 (1975) (observing that 'it is through the flow of behaviour - or more precisely social action - that cultural forms find articulation').

164 Sharon Gilad, Institutionalising Fairness in Financial Markets: Overcoming Resistance, 5 Regulation \& GOVERNANCE 309 (2011).

165 Awrey et al supra note 161 .
} 
generally in relation to executive and non-executive directors. This guidance states, for example, that 'effective boards' provide direction for management, demonstrate ethical leadership and make well informed and high quality decisions. ${ }^{166}$ Importantly, the Code both builds in senior board responsibility for this evaluation - by requiring the Chairman of the board to act on the results - and provides the means of imposing discipline on this evaluation process through: an annual report to shareholders on the evaluation; performance evaluation of the chairman led by the senior independent director; and a tri-annual facilitation of this performance review through an external facilitator. ${ }^{167}$

The effects of this process-based approach remain invisible to external scrutiny, which renders it unstable in the face of high profile failure. However, in contrast to other areas of regulation where this technique is deployed ${ }^{168}$ there are good reasons to be optimistic about its effects. The board, and in particular, the non-executive directors and the chairman have strong incentives to take, and to be seen to be taking, board performance and evaluation seriously. Failure to do so puts at risk their reputational capital.

\section{CONCLUSION}

A typical caricature of self- or market-controlled regulation is that it serves the needs only of the regulated constituencies by producing rules that purport but fail to really address the problems that require regulatory attention, and which are rarely enforced against their 'kin'. We see from the examples of self- and marketcontrolled regulation in the UK discussed in this chapter that, paradoxically, this is palpably not the case in corporate law. In the context of both takeover regulation and corporate governance codes we find rule overload and rigorous enforcement. Do these examples then provide model forms of regulation that other jurisdictions would be well advised to emulate? Has corporate law missed a trick in failing to employ more broadly such regulatory devices? The analysis in this chapter suggests that there is significant doubt that that is the case. The rule-content and enforcement overload in both the context of takeovers and comply or explain codes appear in part to the product of regulatory malfunction. In relation to takeovers such overload may be a function of rent seeking itself - the investment banking role, which in the context of enforcement generates a positive regulatory dividend but may be a factor in the production of what is now a 300 page Code. In the context of comply or explain codes over-enforcement generates a best practice, accountability driven code from which opt-outs are in many instances

166 FRC, Guidance on Board Effectiveness (2011), 2 (available at: https://www.frc.org.uk/OurWork/Publications/Corporate-Governance/Guidance-on-Board-Effectiveness.pdf).

167 UK Corporate Governance Code, B.6.2.

168 For example, in the context of retail financial regulation. See generally, Awrey et al supra note 161. 
impracticable even though such a best practice outlook is premised on the possibility of opt-out.

The diffusion of market-controlled comply or explain codes shows that such innovations are clearly replicable. Any state can direct market actors to produce rules and can deploy the process-based tool-kit which we see used in the UK Corporate Governance Code's board evaluation requirement. But in relation to endogenous self-regulation where the state does not have a direct role, the analysis in this chapter does not hold out significant hope for effective replication where market actors - in jurisdictions such as in Brazil today in the takeover context attempt to provide welfare enhancing regulatory solutions where the state has failed to do so. The UK Takeover Panel and Code is in multiple respects a sui generis regulatory product. That said the analysis in this chapter suggests that if there is one lesson which it offers in the hope of making it work it is 'bribe your quarterback': bond the investment banking community to your regulatory product by showing them that it can generate income. If successful, it may be that you end up with a 300 page code! Maybe the trade-off is worth the candle. 